\title{
Diriliş Sonrası Siklusu İçerisinde İki Sahne: Emmaus Yolunda ve Emmaus'da Akşam Yemeği
}

\author{
Two Scenes in the Post-Resurrection Cycle: On the Road to Emmaus and the Supper at \\ Emmaus
}

\section{Hatice Demir}

Öz

Bu çalışmada Emmaus Yolunda ve Emmaus'da Akşam Yemeği sahneleri incelenmiştir. Diriliş Sonrası siklusu içerisinde yer alan iki sahne, Doğu/Bizans tasvir sanatında nicel olarak az yer alırken, sahnelerin Batı/Latin örneklerinde sayıca fazla olması dikkat çeker. Doğu örneklerinde, sahnenin en erken tarihli örneği 6. yüzyıla tarihlenen Sant’Apollinore Nuovo bazilikasında görülürken, Batı örneklerinde en erken tarihli örnek, 9. yüzyıla ait bir fildişi levhaya aittir. Diğer taraftan Latin örneklerinin daha çok resimli el yazmalarında tercih edildiği gözlemlenir. Çalışmanın kapsamı iki alt başlık altında ele alınmıştır. İlk grupta, Doğu/Bizans örnekleri, ikinci alt başlık altında Batı/Latin örnekleri incelenmiştir. Değerlendirme bölümünde sahneler, kendi aralarında kıyaslanmıştır. Bu bağlamda, Doğu örneklerinin az olmasına karşın, Batı örneklerinin nicel olarak çok olması sorunsalına cevaplar bulunmaya çalışılmıştır. Değerlendirme kapsamında ele alınan noktalardan bir diğerini, ikonografik detaylar oluşturmuştur. Bu bağlamda her iki sahnenin ikonografisinde farklı yorumlar ile karşılaşılmıştır. Değerlendirme bölümünde, cevap aranan en önemli nokta ise bu detaylardaki farklılıkların kaynağının neler olabileceğine dair sorulardır. Çalışma kapsamında incelenen örneklerin (Bizans ve Latin) tarihleri, içlerinde bir eşzamanlılık olması adına 14. yüzyıl sonu ile sınırlandırılmıştır.

\section{Anahtar Kelimeler}

Emmaus Yolu, Akşam Yemeği, Diriliş Sonrası, İsa, Resim

\begin{abstract}
This study examines scenes from two important 14th-century tableaus depicting Christ with his disciples: On the Road to Emmaus and the Supper at Emmaus. While such portrayals of the post-Resurrection cycle were rare in Eastern/Byzantine art, they were far more prevalent in Western/Latin art. The earliest example of On the Road to Emmaus in Eastern art is at the Basilica of Ravenna Sant'Apollinare Nuovo, dating to the $6^{\text {th }}$ century. The earliest instance in Western art is a $9^{\text {th }}$-century depiction on an ivory plaque. Latin samples of the scenes are popular in illustrated manuscripts. The study scope can be divided into two parts. The first part examines Eastern/Byzantine examples and the second part analyzes Western/Latin samples per a hierarchical classification. In the conclusion and evaluation section, the selected examples are compared. Eastern examples of the two scenes are rare and quantitatively outnumbered in Western/Latin art. This study explores the reasons for the rareness of these scenes in Eastern art and their abundance in Western art; different interpretations of the same are presented in the conclusion. Finally, the iconography of the two scenes differs in Eastern and Western examples. Therefore, our evaluation is focused on solving these questions. Our primary aim was to answer
\end{abstract}

* Sorumlu Yazar: Hatice Demir (Dr. Öğretim Görevlisi), Kastamonu Üniversitesi, Sosyal Bilimler Enstitüsü, Kastamonu, Türkiye. E-posta: haticedemir99@hotmail.com, ORCID: 0000-0002-5801-5841

Atıf: Demir, Hatice. "Diriliş Sonrası Siklusu İçerisinde İki Sahne: Emmaus Yolunda ve Emmaus'da Akşam Yemeği." Art-Sanat, 16(2021): 123-149. https://doi.org/10.26650/artsanat.2021.16.0005 
these problematic questions on the sources and reasons for the differences in iconography. The selection of the Byzantine and Latin samples was limited to those from the end of the $14^{\text {th }}$ century to evaluate them in their synchronicity.

Keywords

Emmaus Road, Supper, Post-Resurrection, Christ, Byzantine Painting

\section{Extended Summary}

In Christian art, the Christ cycle includes scenes of his life divided into various sub-cycles. Some of these sub-cycles depict the infancy cycle beginning with the Annunciation to Mary and Nativity of Christ, Miracles of Jesus, and Passion of Christ. The post-Resurrection cycle starts after the Descent from the Cross and Entombment scenes. The post-Resurrection cycle scenes are as follows: Myrrhbearers/Myrophoroi/ Marys at the Tomb, Chairete, Noli me Tangere, Peter and John at the Tomb/Empty Tomb, the Incredibility of Thomas, the Miraculous Catch of Fish/Miraculous Draught of Fish(es), On the Road to Emmaus, the Supper at Emmaus, Christ Appears to the Eleven, and Anastasis. The Anastasis scene is different from the other post-Resurrection cycle scenes for lacking a direct reference to the post-Resurrection events of the Synoptic Gospels. Hades, a pagan period element, is the most obtrusive iconographic detail of the Anastasis scene. Hades is an indirect biblical element of the scene originating from the term "Sheol/grave" in Psalm 16:10 and "the realm of the dead" in Acts 2:27. All the post Resurrection cycle's scenes are prevalent after Iconoclasm. The Incarnation of Christ, consisting of both his human and divine nature, was one of the main topics discussed in the Iconoclastic period. Opposite to Iconoclastic supporters, the Iconodule supporters believed in Christ and revered depictions of him related to his incarnation. Therefore, post-Resurrection scenes were a testimony to his personification and a political manifestation up to this era. As a result of this manifestation, the scenes were ubiquitous in every area of art.

Of the Eastern samples of Road to Emmaus, the first is at the Basilica di Sant'Apollinare Nuovo, Ravenna; it dates to the $6^{\text {th }}$ century. Only three examples have been identified in book illumination. The earliest dates to the $11^{\text {th }}$ century, whereas the latest one is a copy. The latest examples of the two scenes in Eastern art at the Serbia Gračanica Monastery date to the $14^{\text {th }}$ century. The earliest examples of the scenes are on a plaque dated to the $9^{\text {th }}$-century Carolingian period in Western art. These depictions are seen frequently in Western book illuminations. When the Eastern and Western examples are compared, the differences in iconographical details are notable. These differences were also apparent in the architectural details of the Emmaus. It is unclear where Emmaus is today. Especially after the Crusades, many Latin-centered villages were named Emmaus, and sanctuaries were built along the sacred pilgrimage routes to the holy lands. The architectural details of these various pilgrimage sites 
belonged to different religious groups, such as the Franciscans. The Dominican Order is visible in the depiction of Emmaus. In some examples, the village buildings were depicted with church-like architectural details, whereas in some parts, the city walls appear prominently in both scenes. Other iconographical differences are visible in the physical depictions of Christ and his two followers. In Eastern examples, Christ and his two followers are usually depicted in chiton and himation. In Western scenes, Christ wears a nonwoven cloak, carries a shoulder bag, with a cap on his head, and holds a shepherd scepter in his hand. With these clothes, he appears like a shepherd. Both in Eastern and Western examples, the two followers of Christ are generally depicted without a halo. One of his followers' names was Cleopas, but the other's name is unknown. These two figures were not Christ's disciples. He had only two followers. In the Bible, the followers' number between 70 and 120. Because of not being disciples of Christ, they appear without halos in many cases. The last iconographical detail discussed in this study is the supper table in Emmaus. As memorialized in Luke 24:30, Christ broke a loaf of bread and gave it to his disciples. According to Luke's reference, in Eastern samples, a loaf of bread is the main iconographical element in the scene, but in Western depictions, apart from a loaf of bread, some drinking cups, fish, and a knife can also be seen on the table. These details do not match the Bible's scriptural references.

Consequently, the two scenes (On the Road to Emmaus and the Supper at Emmaus) are not popular in Christian art. This study introduces these two scenes because they are an essential testimony to Christ's post-Resurrection depiction, as the Anastasis scene. 


\section{Giriş}

İsa'nın hayatından kesitler içeren İsa siklusu' ${ }^{1}$, kendi içerisinde çeşitli alt bölümlere ayrılır. Meryem'e Müjde sahnesi ile başlayan doğum-bebeklik-çocukluk siklusu, İsa'nın mucizelerinin de yer aldığı İsa'nın hizmetlerini anlatan sahnelerden oluşan siklus, çarmıha gerilme ile başlayan ve İsa'nın mezara konulmasına kadar devam eden sahnelerden oluşan İsa'nın Çilesi siklusu ve bu çalışmanın konusunu oluşturan, Emmaus Yolunda ve Emmaus'da Akşam Yemeği sahnelerini de içeren Diriliş Sonrası siklusu şeklindedir.

İsa'nın Çilesi siklusunun bir devamı olan Diriliş Sonrası siklusu²; Mezar Başında Meryemler/Myrophoroi/Mür Taşıyan Kadınlar (Matta 28: 1-8, Markos 16: 1-8, Luka 24: 1-12, Yuhanna 20: 1), Chairete (Matta 28: 9-10), Noli me Tangere (Yuhanna 20: 11-18), Petrus ve Yuhanna Mezar Başında (Yuhanna 20: 2-8), Thomas'ın Şüphesi/ Şüpheciliği ${ }^{3}$ (Yuhanna 20: 24-29), Balıkların Çoğalışı (Yuhanna 21: 1-23) ${ }^{4}$, Emmaus Yolunda ve Emmaus'da Akşam Yemeği ${ }^{5}$ (Markos 16:12-13, Luka 24: 13-15), İsa, Onbirler'e Görünüyor (Luka 24: 36-49) ve Anastasis sahneleri şeklindedir.

Emmaus Yolunda ve Emmaus'da Akşam Yemeği, Luka 24: 13-32'de geçer. Markos 16: 12-13'de ise dolaylı bir vurgu vardır. Sahneler, Luka 24: 13-32'de Emmaus Yolunda İki Öğrenci adı ile bahsedilir. Olayın hikayesi kısaca şöyledir: İsa'nın mezarından dirilmesi ve Mür Taşıyan Kadınlara görünmesinin aynı günü, Kudüs’ten Emmaus'a giden Klopas $^{6}$ ve adı bilinmeyen bir diğer öğrenci, aralarında olanları konuşup tartışırken

1 Çalışma kapsamında İngilizce "cycle" ifadesinin çevirisi, Türkiye'de Bizans resim sanatında yaygın olarak kullanılan "siklus" ifadesi ile verilmiştir. Ancak ifadenin "çevrim" olarak kullanımı da mevcuttur.

2 Yukarıda bahsi geçen ve İsa siklusu içerisinde küçük bir siklus oluşturan Diriliş Sonrası siklusu tanımı, Konis tarafından yapılmıştır. Konis, İsa'nın Diriliş Sonrası siklusu içerisinde yer alan sahneleri ayrıntılı bir biçimde ele almıştır. Geniş bilgi için bk. Polyvios Konis, "From the Resurrection to the Ascension: Christ's Post-Resurrection Appearances in Byzantine Art (3rd - 12th c.)" (Doktora tezi, Birmingham Üniversitesi, 2008), 1-12.

3 Thomas'ın Şüphesi/Şüpheciliği, Yuhanna 20:24-31'de geçer. Bizans sanatında sahne, Yuhanna 20:26'ya istinaden "Kapattlan Kapılar" ya da Yuhanna 20:28'e istinaden "Efendim ve Tanrım" adıyla da anılır. Sahne, İsa'nın enkarnasyonuna bir delil niteliği taşıyan ve 4.-5. yüzyıllara kadar uzanan, en erken dönem ikonografilerden biridir. Geniş bilgi için bk. Konis, "From the Resurrection to the Ascension: Christ's Post-Resurrection Appearances in Byzantine Art (3rd - 12th c.)", 4-5.

4 Luka 5:1-11'de ilk mucizevi balık tutma olayı yer alır. Yuhanna 21:1-14'te ise İsa dirildikten sonra havarilerine görünür ve mucizevi balık tutma olayı ikinci kez gerçekleşir.

5 Luka 24:13-35 Emmaus Yolunda hikayesini, Diriliş hikâyeleri içerisinde en gerçekçi olarak görür. Geniş bilgi için bk. Norman Huffman, "Emmaus Among the Resurrection Narratives," Journal of Biblical Literature 64/2 (1945), 215.

6 Kleopas, Aramice'de, חילפא/Klopas olarak geçer. Adı verilmeyen öğrencinin kim olabileceği konusunda Huffman; Nathaniel, Luka ya da Simon olabileceği görüşünü savunur. Bu isimlerden Simon üzerinde ayrıntılı durur. İkinci Kudüs piskoposu Simon'un, Yusuf'un kardeşi Klopas olduğuna vurgu yapar. Geniş bilgi için bk. Huffman, "Emmaus Among the Resurrection Narratives," 218, dipnot 30. Eusebius (4. yüzy1l) Klopas'ın, Yusuf'un kardeşi yani İsa'nın üvey amcası olabileceği ihtimali üzerinde durur. Klopas'ın, Yuhanna 19:25'te, "Isa'nın çarmıhının yanında ise annesi, teyzesi, Klopas'ın karısı Meryem ve Mecdelli Meryem duruyordu." ifadesinde geçen Klopas olma ihtimali de söz konusudur. Geniş bilgi için bk. Derek Morris, "The Emmaus Road-Part 1-2-3, The Testimony of Cleopas," 2-3, erişim 21 Ocak 2021. https://trilogyscriptureresources. com/wp-content/uploads/2013/04/Emmaus-Road.pdf ; Fournalı Dionysius'un Ressam Kılavuzu kitabında 
İsa yanlarında belirir ve onlarla yürümeye başlar. İki öğrenci, yanlarında yürüyenin kim olduğunu anlayamadıkları için onunla İsa'nın diriliş olayını tartışırlar. Akşam üzeri Emmaus'a vardıklarında, İsa yola devam etmek ister ancak öğrencileri, onu kendileri ile kalmaya ikna eder. Akşam yemeğinde İsa ekmeği böldüğü esnada, öğrencilerin gözleri açılır ve İsa'yı tanırlar ancak o anda İsa gözden kaybolur. İki öğrenci bunun üzerine hemen Kudüs'e dönerler ve olanları Onbirler'e ve diğerlerine anlatırlar.

Markos 16: 12-13'de ise olay: “Bundan sonra İsa kirlara doğru yürümekte olan öğrencilerinden ikisine değişik bir biçimde göründü. Bunlar geri dönüp diğerlerine haber verdiler, ama diğerleri bunlara da inanmadılar." şeklinde daha kısa bir ifade ile aktarılır.

\section{Emmaus ile İlgili Tarihi Veriler}

Luka İncili 24:13’te, “...Yeruşalim'den altmış ok atımı uzaklikta bulunan ve Emmaus denilen bir köye gitmekteydiler." ifadeleri ile geçen Emmaus'un günümüzdeki yerinin tam olarak neresi olduğu belli değildir. Routley, Nikopolis (Imwas/Amwas), Abu Ghosh, El-Qubeibeh/Al-Qubeiba ve Qaloniyeh/Colania/Motza gibi arkeolojik alanların Emmaus olabileceği yönünde görüş belirtir? . Kudüs ve Beytüllahim kentlerinde olduğu gibi, surlarla çevrili bir yerleşim yeri olmama ihtimalinin yüksek olduğu Emmaus, Kudüs'ten yaklaşı 7-8 mil uzaklıkta küçük bir yerleşim yeri olarak bilinir'. Emmaus'un, Kudüs'e bağlı küçük bir yerleşim yeri olduğu bilgisi yine bizzat Kitab-ı Mukaddes referansları

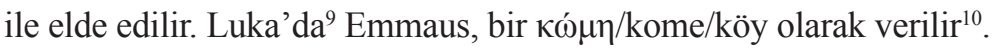

Diğer taraftan Emmaus'un kelime anlamı nedeniyle tek bir şehre özel bir isim olmama ihtimali de söz konusudur. Emmaus İbrani kaynaklarında ve ayrıca Eski Yunanca' da "llık kuyu, pınar" anlamına gelmektedir. Ecclesiastes Rabbah"11 7:15'te: "iyi su, iyi yerleşim yeri" olarak da geçer. Emmaus'un etimolojik kökeni için önerilen ve

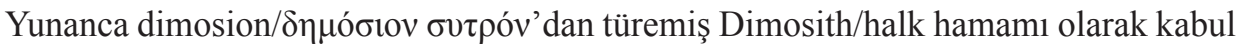
edilen başka bir kelime daha vardır. Emmaus'un şifa veren suyuna atıflar, bizzat Bizans kaynaklarında da verilir ${ }^{12}$. Emmaus'un sıcak-şifalı su ve kaplıca gibi anlamlara

Klopas ile birlikte Luka ismi verilir. Geniş bilgi için bk. The 'Painter's Manual' of Dionysius of Fourna an English Translation with Commentary, of cod. gr. 708 in the Saltykov-Shchedrin State Public Library, Leningrad, çev. Paul, Hetherington, (London: The Sagittarius Press, 1974), iii, madde 214-21.

7 Geniş bilgi için bk. Jonathan Routley, "Finding Emmaus: The Problem of the Geographical Location of the Biblical Site, ” erişim 22 Ocak 2021,

https://www.academia.edu/37192570/Finding_Emmaus_The_Problem_of_the_Geographical_Location_of_ the_Biblical_Site.

8 , Morris, "The Emmaus Road-Part 1, The Testimony of Cleopas," 3.

9 Kome, sadece Yeni Ahit ve Elçilerin İşleri’nde geçmektedir. Matta 9:35, Markos 8:27, Markos 16:12-13 ve Luka 9:12.

10 Yeni Ahit’te polis=şehir, kome=köy ve argos=kırsal olmak üzere bir kent hiyerarşisi verilmiştir. Bu bağlamda, Emmaus'un Kudüs kent merkezine yakın sessiz bir kırsal olma ihtimali yüksektir. Geniş bilgi için bk. Routley, "Finding Emmaus: The Problem of the Geographical Location of the Biblical Site," 3.

11 Vaiz Rabbah'ın aggadik/yasal olmayan yorumlarını/tefsirlerini içeren bir kitaptır.

12 Routley, "Finding Emmaus: The Problem of the Geographical Location of the Biblical Site," 1, dipnot 4. 
gelmesi nedeniyle, bölgedeki kaplıca suları olan diğer başka yerler de Emmaus ismi ile anılmışlardır ${ }^{13}$.

\section{Doğu/Bizans Örneklerinde Emmaus Yolunda ve Emmaus'da Akşam Yemeği Sahneleri}

Çalışma kapsamında Emmaus Yolunda ve Emmaus'da Akşam Yemeği sahneleri iki alt kategori altında ele alınmıştır. İlk grupta Doğu/Bizans kökenli örneklere yer verilirken, ikinci grupta Batı/Latin kökenli örnekler üzerinde durulmuştur ${ }^{14}$.

Bizans ya da Bizans etkili Doğu tasvir örneklerinde, her iki sahnenin nicel olarak azlığı dikkat çeker. En erken tarihli örnek, 6. yüzyıla tarihlenen Sant' Apollinare Nuovo Bazilikası'nda yer alır. Sahnede, koyu renk himation ve khiton giyimli İsa, açık renk khiton üzerine turuncu ve altın renkli himation giyimli iki öğrencisi ile Emmaus Yolu'nda yürürlerken tasvir edilmişlerdir. Sahnede, açık-düzlük bir alan, kısmen yeşillikler içerisinde Emmaus'u gösteren binalar görülür (G. 1).

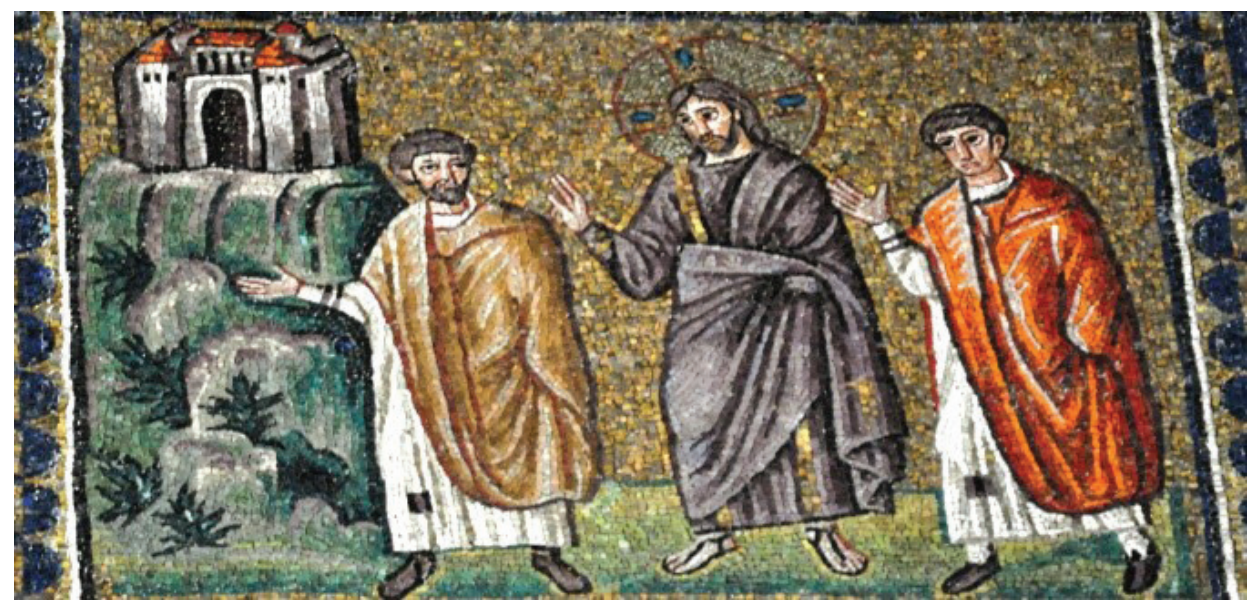

G. 1: Emmaus Yolunda Sahnesi, Sant' Apollinare Nuovo Bazilikasi/Ravenna, Mozaik Pano, 6. Yüzyıl (Görsel, Hatice Demir Arşivi, 2017)

11. yüzyıla tarihlenen ve günümüzde Berlin Bode Müzesi’nde muhafaza edilen oyma ve kazıma teknikleriyle yapılmış kemik levhada, Emmaus'da Akşam Yemeği sahnesi yer alır. Arka fonda, Emmaus'u gösteren mimari yapılar, ön düzlemde ise bir masa etrafında oturan İsa ve iki öğrencisi vardır. İsa'nın bir ekmeği bölerken tasvir edildiği sahnede, İsa'nın haleli ancak iki öğrencisinin halesiz oldukları gözlemlenir (G. 2).

13 Routley, "Finding Emmaus: The Problem of the Geographical Location of the Biblical Site," 1-2.

14 Batı örneklerinde her iki sahnenin özellikle geç dönem tasvir sanatında yaygın olduğu gözlemlenir. Ancak çalışma örnekleri 15. yüzyıla kadar olan örnekler ile sınırlı tutulmuştur. 


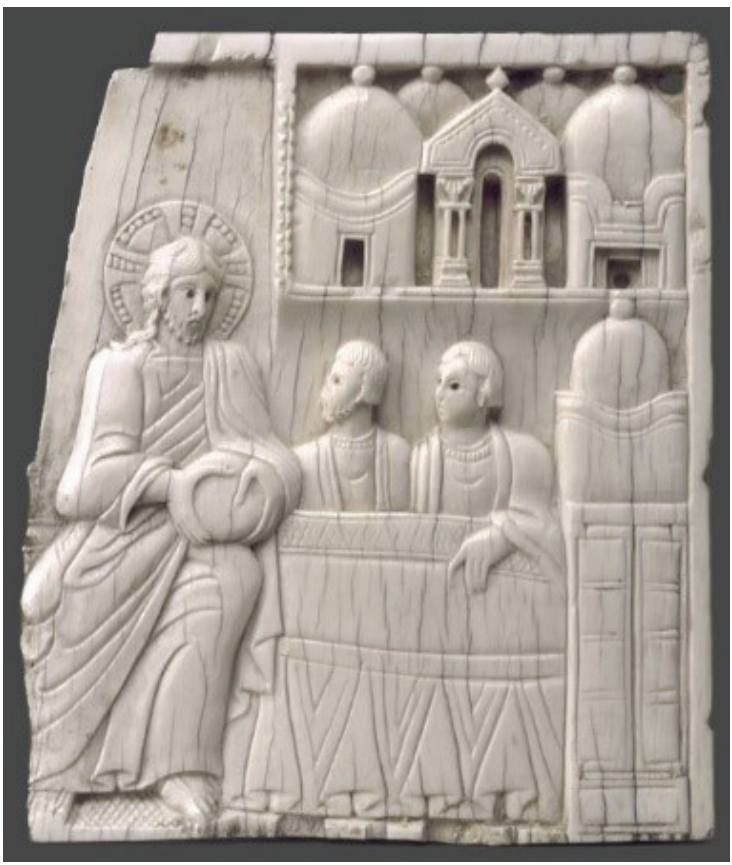

G. 2: Emmaus'da Akşam Yemeği Sahnesi, Kemik Oyma Levha, $\left({ }^{\circ}\right.$ Berlin/Bode Müzesi/ Museum für Spätantike und Byzantinische Kunst/SMPK), 10.2 x 11,9 cm., Kemik Oyma Levha, 11. Yüzyıl https://www.ruicon.ru/arts-new/carving/1x1-dtl/po_kosti/raspyatie hristovo35/?page_19=10\&p_f_23_temp_id=1\&p_f_23_1=1\&ref-cat=
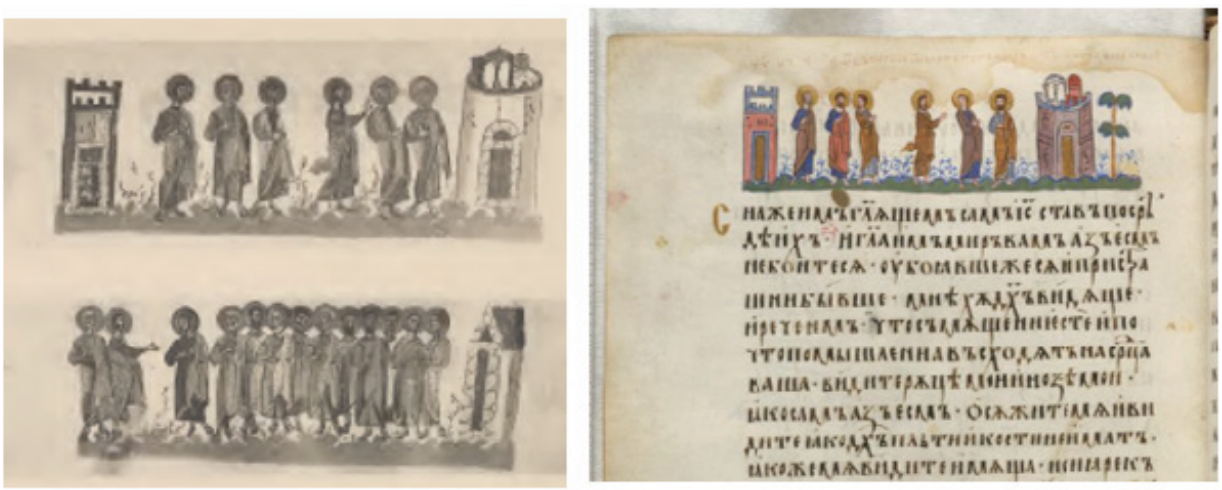

G. 3: Emmaus Yolunda Sahnesi (üstte), İsa'nın Onbirlere/Havarilere Görünmesi Sahnesi (altta), Cod. gr. 74, fol. 162v. 11. Yüzyıl (Omont 1908, fig. 141), $\left({ }^{\circ}\right.$ Paris BnF) (Solda)

G. 4: Emmaus Yolunda Sahnesi, Add MS 39627 Çar Ivan Aleksandr İncilleri, fol. 211v., 14. Yüzyıl ( $\left({ }^{\circ}\right.$ British Library) (Sağda) http://www.bl.uk/manuscripts/

Viewer.aspx?ref=add_ms_39627_f162v 
Sahneler, Bizans dönemi resimli dinî el yazmalarında da azdır ${ }^{15}$. 11. yüzyıla tarihlenen ve Paris Millî Kütüphanesi'nde muhafaza edilen Cod. gr. 74 fol. 162v.' de ${ }^{16}$, iki sahne birlikte verilmiştir. Üstte, Emmaus Yolunda, altta ise İsa, Onbirler'e Görünüyor sahneleri yer alır (G. 3).

Seçilen örnekler kapsamında 14. yüzyıla tarihlenen bir başka el yazması Bulgaristan Çar Ivan Aleksandr Incilleri fol. 211v. kitap resmi ufak detaylar dışında, Cod. gr. 74 fol. 162v. örneğini tekrarlar (G. 4).

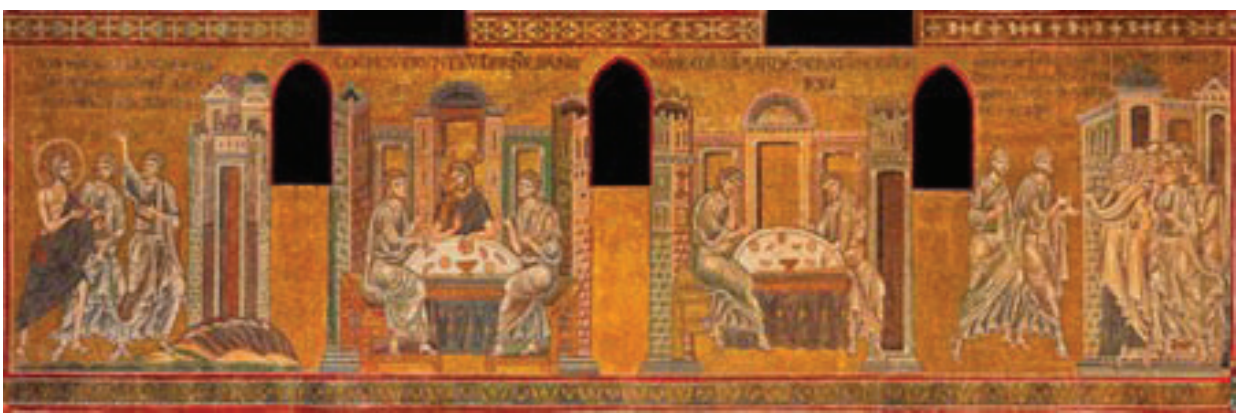

G. 5: Diriliş Sonrası Siklusu Sahneleri Soldan Sağa: Emmaus Yolunda-Emmaus'da Akşam Yemeği-İsa'nın Emmaus'da Akşam Yemeğinden Kayboluşu-Öğrencilerin Kudüs'e Giderek Olanları Diğerlerine Anlatması Sahneleri, Palermo/Monreale Katedrali, Mozaik Pano, 12. Yüzy1l, (http://www.duomomonreale.it/index2710.html? option=com_content\&task=view\&id=186\&Itemid=252\&lang=en)

12. yüzyıla tarihlenen Palermo/Monreale Katedrali mozaik pano örneğinde, Diriliş Sonrası siklusu sahneleri: Emmaus Yolunda-Emmaus'da Akşam Yemeği ve İsa'nın Emmaus'da Akşam Yemeğinden Kayboluşu-Öğrencilerin Kudüs'e Giderek Olanları Diğerlerine Anlatması şeklindedir. Eşit panolara bölünen sahnelerde, aynı kıyafetler içerisindeki figürler, hareketli vücut ifadeleri ile tasvir edilmiştir (G. 5).

Doğu/Bizans resim sanatı kapsamında seçilen son örnek 14. yüzyıla tarihlenen, Sırbistan Gračanica/Graçanitsa Manastırı'na ait bir duvar resmidir. Diriliş Sonrası siklusu sahneleri: Emmaus Yolunda-Emmaus'da Akşam Yemeği-Öğrencilerin Kudüs'e Giderek Olanları Diğerlerine Anlatması şeklindedir. Sahnede, Emmaus Yolu dağlık bir patika içerisinde yer alırken, Emmaus'daki öğrencilerin evleri ve öğrencilerin Kudüs'e dönerek olanları diğerlerine anlatması sahnesinde, arka plandaki mekânda kesintisiz bir mimari tasvir söz konusudur (G. 6).

15 Diğer bir el yazması örneği Floransa Biblioteca Laureziana Kütüphanesi'nde muhafaza edilen Laur. VI. 23, fol. 164r. kitap resmi örneğidir. Geniş bilgi için bk. Tania Velmans, Le Tétraévangile de la Laurentienne Florence, Laur.VI 23, (Paris : Bibliothèque des Cahiers Archéologiques/6, 1971), 48, fig. 266.

16 Geniş bilgi için bk. Henri Omont, Evangiles avec Peintures Byzantine du XIe siecle. Tome II, Reproduction des 361 miniatures du Manuscrit Grec 74 de la Bibliothèque Nationale, (Paris : Berthaud frères,1908), 141. 


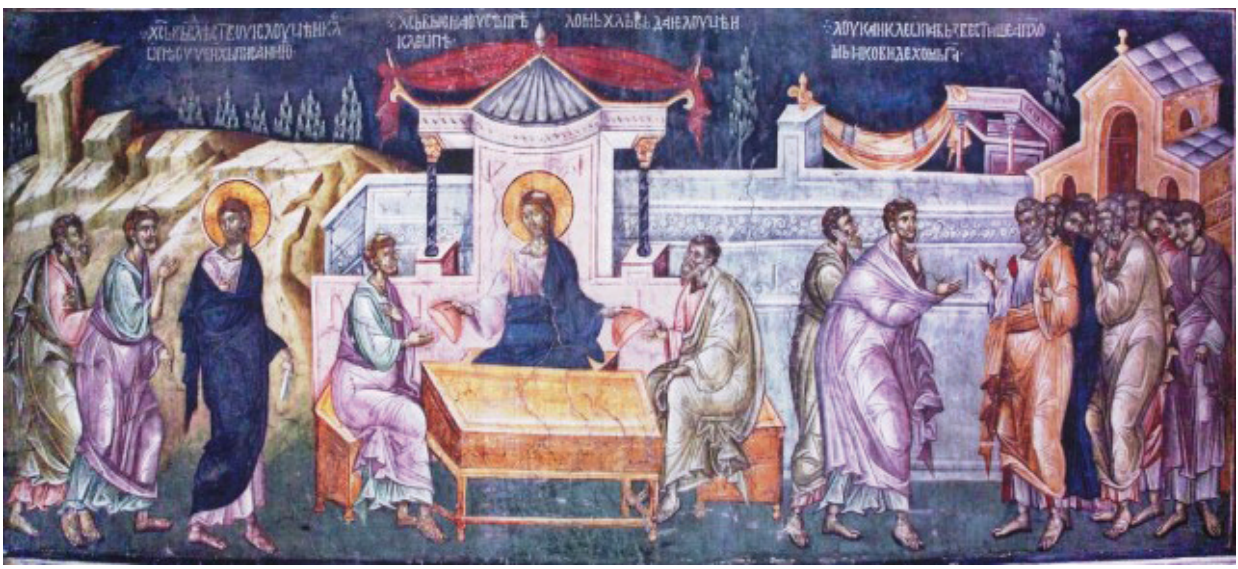

G. 6: Diriliş Sonrası Siklusu Sahneleri-Soldan Sağa: Emmaus Yolunda-Emmaus'da Akşam Yemeği-Öğrencilerin Kudüs'e Giderek Olanları Diğerlerine Anlatması Sahneleri,

Sırbistan Graçanitsa/Gračanica Manastırı, Duvar Resmi, 14. Yüzyıl

(https://russianicons.wordpress.com/tag/road-to-emmaus/)

\section{Batı/Latin Resim Örneklerinde Emmaus Yolunda ve Emmaus'ta Akşam Yemeği}

Batı/Latin resim sanatı örnekleri için seçilen en erken tarihli örnek, 9. yüzyıla aittir. Kuzey Fransa Karolenj Dönemi üretimi fildişi levhada, Emmaus Yolunda ve Emmaus'da Akşam Yemeği birlikte verilmiştir (G. 7).

Sadece İsa'nın haleli olduğu tasvirde, üç figürün kıyafetleri hemen hemen aynıdır. İsa, eliyle ters yönü gösterirken, diğer iki figür/öğrenci, onu Luka 24: 28-2917 referanslı olarak Emmaus'daki evlerine birlikte gitmeye ikna ederken betimlenmişlerdir. Emmaus, sur içerisinde bir yapı topluluğu şeklinde verilmiştir. Mimari yapıların tam merkezinde, iki öğrencinin evinde masa etrafında, İsa'nın elinde bir somun ekmeği tuttuğu gözlemlenir (G. 7).

Dombibliothek Hildesheim'da muhafaza edilen 1120-1130 tarihli Londra Aziz Albans Benedikt Manastırı üretimi Aziz Albans Psalter'1 kitap resimlerinde, Emmaus Yolunda- Emmaus'da Akşam Yemeği ve İsa'nın Emmaus'da Akşam Yemeğinden Kayboluşu sahneleri yer alır ${ }^{18}(\mathbf{G ~ . 8 , ~ G . ~ 9 , ~ G . ~ 1 0 ) . ~}$

17 "Gitmekte oldukları köye yaklaştıkları sırada İsa, yoluna devam edecekmiş gibi davrandı. Ama onlar, "Bizimle kal. Neredeyse akşam olacak, gün batmak üzere” diyerek onu zorladılar. Böylece İsa onlarla birlikte kalmak üzere içeri girdi."

18 1120-1130 tarihleri arasında Kuzey Londra'da Aziz Albans Manastırı'nda üretilen Aziz Albans Psalter' $\iota$, Dombibliothek'e götürüldükten sonra, Dombibliothek, MS St. Godehard adı ile de anılmaya başlanmıştır. Geniş bilgi için bk. https://www.dombibliothek-hildesheim.de/en/st-albans-psalter; Ayrıca bk. https://www. muellerundschindler.com/, Peter Kidd, "Contents and Codicology," Dombibliothek Hildesheim The Albani Psalter. (Simbach am Inn: Verlag Müller \& Schindler, 2008), 87. 


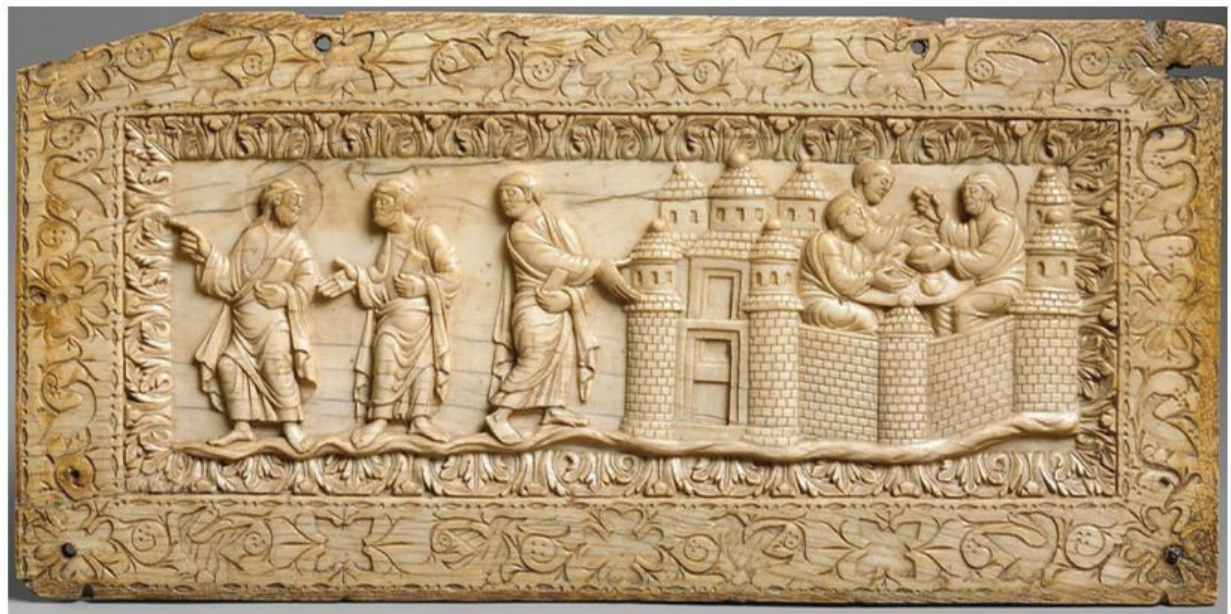

G. 7: Emmaus Yolunda ve Emmaus'da Akşam Yemeği Sahneleri, Fildişi Levha, Kuzey Fransa Üretimi, Karolenj Dönemi, 850-900, (11.5 x 23.5 x 0.6 cm) No: 1970.324.1, Cloisters Koleksiyonu, 9. Yüzy1l ( ${ }^{\circ}$ Met Museum), (https://www.metmuseum.org/ $\mathrm{art} / \mathrm{collection} / \mathrm{search} / 471970)$
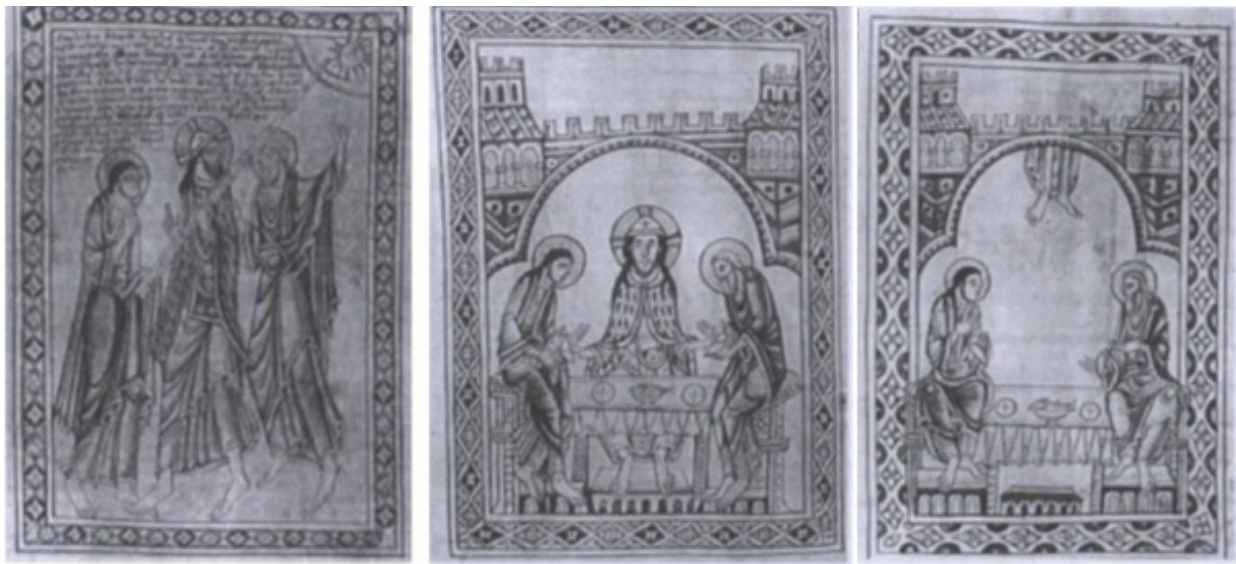

G. 8: Emmaus Yolunda Sahnesi, Aziz Albans Psalter/MS St. Godehardt, 1120-30

$\left({ }^{\circ}\right.$ Dombibliothek Hildesheim), (Evseeva, 2010, Fig. 3. 70), (Solda), https://www.dombibliothek-hildesheim.de/en/st-albans-psalter

G. 9: Emmaus'da Akşam Yemeği Sahnesi, Aziz Albans Psalter/MS St. Godehardt, 1120-30

$\left({ }^{\circ}\right.$ Dombibliothek Hildesheim), (Evseeva, 2010, Fig. 7. 74) (Ortada) https://www.dombibliothek-hildesheim.de/en/st-albans-psalter

G. 10: İsa'nın Emmaus'da Akşam Yemeğinden Kayboluşu Sahnesi, Aziz Albans Psalter/MS St. Godehardt, 1120-30 (Evseeva, 2010, Fig. 8. 74) ( ${ }^{\circ}$ Dombibliothek Hildesheim), (Sağda) https:/www.dombibliothek-hildesheim.de/en/st-albans-psalter 
İsa'nın Emmaus'da Akşam Yemeğinden Kayboluşu sahnesi, British Library'de muhafaza edilen ve 13. yüzyılın başına tarihlenen, Royal MS 1 D X Psalter'1 fol. 7v.'de Thomas'ın Şüphesi/Şüpheciliği sahnesi ile birlikte verilmiştir. Sahnede, ellerinde rulo tutan iki öğrencinin bakışları eşliğinde İsa'nın gözden kayboluş anı betimlenmektedir. Sahnenin hemen altında, Bizans resim sanatında oldukça yaygın olan bir diğer Diriliş̧ Sonrası siklusu sahnesi, Thomas'ın Şüphesi/Şüpheciliği yer alır ${ }^{19}$ (G. 11).

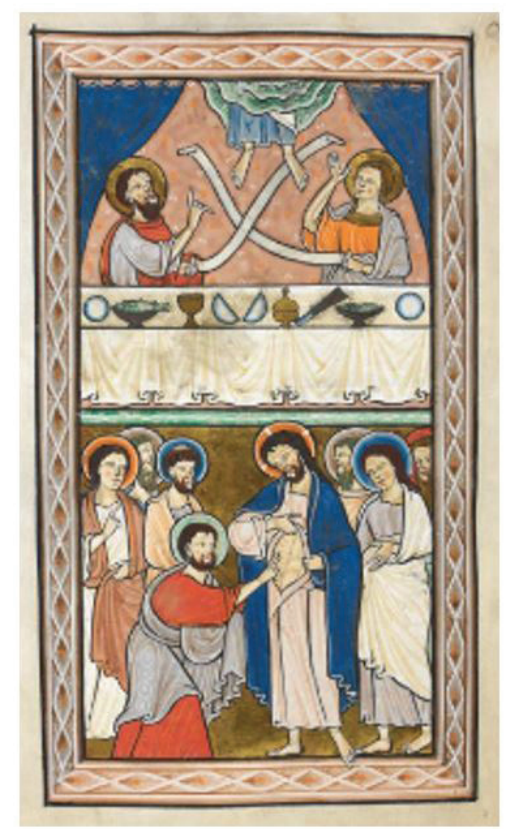

G. 11: İsa'nın Emmaus'da Akşam Yemeğinden Kayboluşu Sahnesi (üstte), Thomas'ın Şüphesi/ Şüpheciliği Sahnesi (altta), Royal MS 1 D X Psalter, fol. 7v., 1200-1220, ( ${ }^{\circ}$ British Library) (Solda). (http://www.bl.uk/manuscripts/Viewer.aspx?ref=royal_ms_1_d_x_fs001r)

19 Thomas'ın Şüphesi/Şüpheciliği sahnesi Yuhanna 20: 24-29 babı bağlantılıdır. Babta olayın hikayesi kısaca şöyledir; İsa, dirildikten sonra 12'lere görünür. O esnada Havari Thomas, diğerleri ile birlikte değildir. İsa'nın dirilip onları ziyaret ettiğini ancak kendi gözüyle gördüğünde ve ellerindeki çivi izlerine dokunduğunda inanacağını belirtir. Sekiz gün sonra İsa onları tekrar ziyaret ettiğinde, İsa, Thomas’a gelip böğrüne dokunmasını ister ve imanlı olması gerektiğini söyler. 


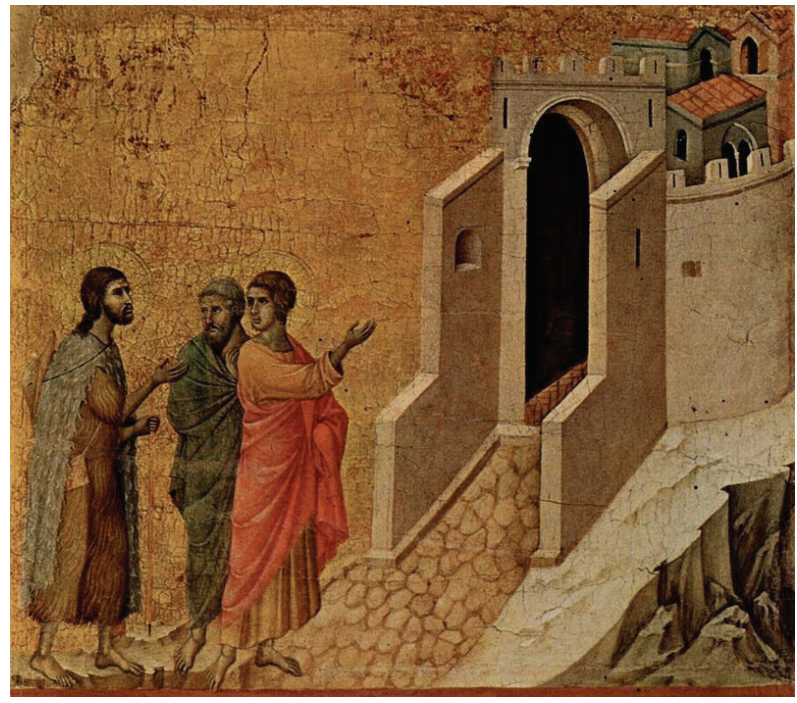

G. 12: Maestà/Altar Pano Parças1, Museo dell'Opera del Duomo/Siena Katedrali (1308-1311), Ressam: Duccio di Buoninsegna, Ahşap Üzerine Tempera Tekniği, 370 x $450 \mathrm{~cm}$. http://www.travelingintuscany.com/art/duccio/maestabackpanels.htm

Kısaca Duccio olarak da tanınan, Orta Çă̆'ın önemli ressamlarından Duccio di Buoninsegna'nın Siena Katedrali için yapmış olduğu altar pano parçası Maestà'nın (1308-1311) ön yüzünde, aziz ve meleklerin eşlik ettiği, kucağında İsa ile tahttaki Meryem/Maestà yer alırken, arka yüzünde 26 sahneden oluşan İsa'nın Çilesi siklusu yer alır. Siklus içerisinde, Diriliş Sonrası sahnelerinden konumuz ile bağlantılı olan Emmaus Yolunda sahnesini de görmek mümkündür ${ }^{20}$ (G. 12). 


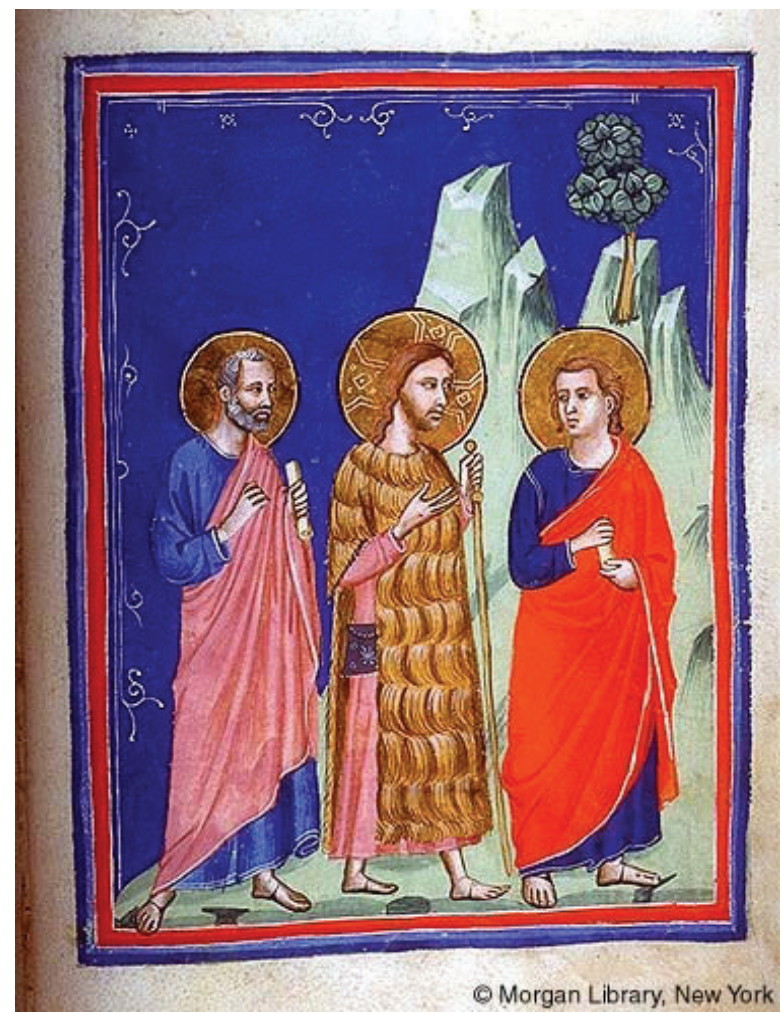

G. 13: Emmaus Yolunda Sahnesi, MS M. 643/Vita Christi, fol. 15r. (1320) ( $\left({ }^{\circ}\right.$ Morgan Library \& Museum) (http://ica.themorgan.org/manuscript/page/28/141641)

1320 tarihli Floransa Pacino di Buonaguida (1303-1347) üretimi olan ve günümüzde Morgan Library \& Museum'da muhafaza edilen MS M. 643 Vita Christi fol. 15r. Emmaus Yolunda ve 15v. Emmaus'da Akşam Yemeği sahnelerinden oluşmaktadır. Fol. 15r.'de, haleli üç figürden ortada yer alan İsa'nın kıyafetleri, diğer ikisinden farklıdır. Öğrenciler, khiton ve himation giyimliyken İsa bir hacının kıyafetlerini andırırcasına, tüylü pelerin, asa ve omuz çantası ile tasvir edilmiştir. Fol. 15v.'de ise, Emmaus'da Akşam Yemeği sahnesinin tasviri vardır (G. 13, G. 14). 


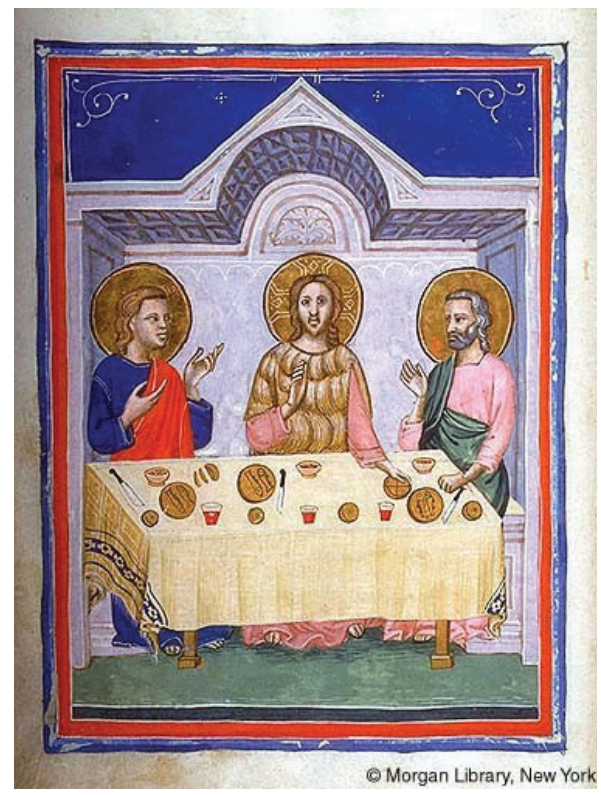

G. 14: Emmaus'da Akşam Yemeği Sahnesi, MS M. 643/Vita Christi fol. 15v. (1320) ( ${ }^{\circ}$ Morgan Library \& Museum) (http://ica.themorgan.org/manuscript/page/29/141641)

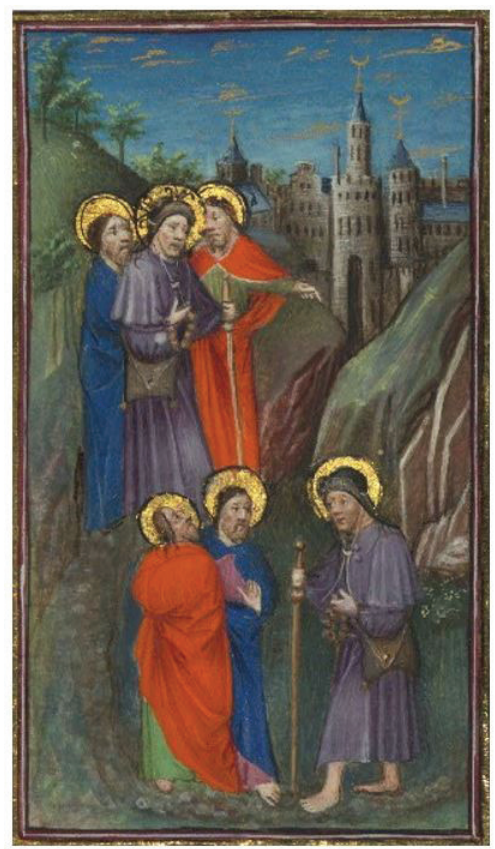

G. 15: Emmaus Yolunda Sahnesi, W. 174/Eberhand von Greiffenklau Dua Kitab1, fol. 99v., s. 204, 15. Yüzy1l ( ${ }^{\circ}$ Walters Sanat Müzesi) (https://thedigitalwalters.org/Data/WaltersManuscripts/ W174/data/W.174/sap/W174_000204_sap.jpg) 
Günümüzde Walters Sanat Müzesinde muhafaza edilen ve 15. yüzyıla tarihlene bir diğer Latin el yazması olan W. 174 Eberhand von Greiffenklau Dua Kitabı ${ }^{21}$ fol. 99v. kitap resmi örneğinde, Emmaus Yolunda sahnesi tasvir edilmiştir. Omuzunda çantası, üzerinde pelerini, başında kasketi ve elinde asası ile İsa, bir hacıya benzemektedir. İsa'nın bu şekilde tasvir edilmesiyle muhtemelen kimliğinin saklanması amaçlanmış olmalıdır. Sahnede, khiton ve himation giyimli iki öğrenci kutsal metin bağlantılı bir ikonografik detay ile ani bir refleksle başlarını arkaya çevirmiş bir şekilde tasvir edilmiştir. Sahnede; dağlık bir patika arasından geçen yolun ufuk çizgisinde Emmaus'u gösteren yapılar yer alır. Resmin üst bölümünde yine Luka 24: 28-29'a istinaden yoluna devam etmek isteyen İsa'yı ikna etmek için öğrencilerden birisi onu tutarken, diğeri ise Emmaus'daki evlerini gösterirken betimlenmişlerdir (G. 15).

\section{Değerlendirme}

Hristiyan tasvir sanatı kapsamında, İsa siklusunun en çarpıcı bölümlerinden birisini İsa'nın Çilesi sahnesi ve sonrasında kendi içerisinde küçük bir siklus oluşturan Diriliş Sonrası sahneleri oluşturur. İsa'nın hem Tanrısal hem de insani yanına vurgu yapan bu sahneler özellikle İkonoklazma ${ }^{22}$ sonrası tasvir yasağının sona ermesiyle birlikte İsa'nın enkarnasyonuna ${ }^{23}$ gönderme niteliğinde bir manifesto özelliği taşır. Doğu resim örneklerinde, özellikle İkonoklazma sonrası Anastasis başta olmak üzere diğer Diriliş Sonrası sahnelerinin yaygın bir biçimde tasvirde yerini aldığı gözlemlenir.

Diriliş Sonrası siklus sahnelerinin, İkonoklazma sonrası sayısındaki çoğalma ikonofil/ikonodül kökenlidir. Bu bağlamda İsa'nın Tanrısal tarafını pekiştirme amaçlı olarak insani tarafı öncelenmiş ve böylece enkarnasyon inancı desteklenmiştir ${ }^{24}$. Diri-

21 W. 174/Eberhand von Greiffenklau Dua Kitabl, 15. yüzyılın ikinci yarısında Utrecht prebendarisi (katedralden ödenek alan papaz) von Greiffenklau için üretilmiştir. Tam sayfa ve zengin renkleri ile kitap resimleri, Felemenk el yazmaları arasında önemli bir yere sahiptir. Geniş bilgi için bk. https://thedigitalwalters.org/ Data/WaltersManuscripts/html/W174/

22 Latince bir kelime olan Iconooclasmus’tan türeyen İkonoklazma terimi, “resim karşıtı” anlamına gelmektedir. Leslie Brubaker, Inventing Byzantine Iconoclasm (Bristol: Bristol Classical Press, 2012), 4. 680-843 tarihleri arasında Bizans Devleti sınırları içerisinde tasvir yasağı dönemi Bizans İkonoklazma dönemi olarak anılır. Bu dönemde, öncelik verilen tasvirler, haç, bitkisel ve hayvansal figürler şeklinde olmuştur. Otto Demus, Byzantine Mosaic Decoration. Aspects of Monumental Art in Byzantium (Boston: Boston \& Art Shop, 1964), 306; Charles Delvoye, "Bizans Resim Sanatının Ana Temayülleri." Ankara Üniversitesi Dil ve Tarih - Coğrafya Fakültesi Dergisi 22/3-4 (1964): 306-307.

23 Enkarnasyon bir inanç ve doktrin olarak Yuhanna 1:14'ü “Söz, insan olup aramızda yaşadı” referans alır. Bu bağlamda Logos'un Tanrısallıktan farklı olarak görünmesi/görünür olması anlamına da gelmektedir. İkonoklazma dönemi Hieria Konsili (754) kararlarından en önemlisi, İsa’nın tasvirleri ve Enkarnasyon Doktrini üzerine gerçekleşen tasvir yasağıdır. Bu karar ile ikona üretiminde, Logos ayrı tutularak sadece İsa'nın eti/ bedeni tasvir edilmiştir. Alexander P. Kazhdan, "Incarnation," The Oxford Dictionary of Byzantium 2. (NewYork/Oxford: Oxford University Press, 1991), 990-991.

24 Geniş bilgi için bk. Kathleen Corrigan, Visual Polemics in the Ninth-Century Byzantine Psalters (CambridgeNew-York : Cambridge University Press, 1992), 88-89 ; André Grabar, "Sur Plusieurs Images Insolites du Christ Dans le Psautier Chloudov," $\triangle X A E, I V / 10$ (1980-81), 11-16; André Grabar, L'Iconoclasme Byzantine, Le Dossier Archéologique (2ed.) (Paris: College de France, 1984), 239-242; Anna Kartsonis, Anastasis, The Making of an Image (Princeton: Princeton University Press, 1986), 138, 228-29. 
liş Sonrası sahnelerinin özellikle 9. yüzyı1, ikonoklazma sonrasında yaygınlaşması bu nedenle siyasi bir manifesto olma niteliği de gösterir ${ }^{25}$. İkonodül taraftarları, İsa'nın tasvirlerinin yasaklanmasını, onun enkarne olması gerçekliğini reddetmek anlamına geldiğini savunmuşlardır.

Sahnelerden: Anastasis, Mür Taşıyan Kadınlar, Chairete ve Thomas’ın Şüphesi/ Şüpheciliği sahneleri en erken tarihli Diriliş Sonrası sahneleridir ${ }^{26}$. Özellikle Mür Taşıyan Kadınların en erken örnekleri, tartışmalı da olsa 3. yüzyıla tarihlenen Dura Europos vaftizhanesinde görülür ${ }^{27}$.

Diriliş Sonrası siklusu içerisinde Anastasis sahnesinin yer alması, bazı tartışmaları da beraberinde getirmiştir. Mür Taşıyan Kadınlar ile başlayan siklusun son sahnesi, İsa’nın Onbirler'e Görünmesi sahnesidir. Snoptik İncillerin Diriliş Sonrası olaylarının aktarıldığg1 olaylar silsilesinde, Anastasis sahnesi ${ }^{28}$ doğrudan Kitab-1 Mukaddes bağlantılı bir sahne olmaması adına diğer sahnelerden de ayrılır. Bu bağlamda, yine yukarıda belirtilmiş olduğu gibi İkonoklazma sonrasında yaygın bir şekilde tercih edilen sahnelerden biri olan Anastasis, her ne kadar doğrudan İsa'nın Diriliş anı ve sonrası sahneler ile ilintili olmasa da 9. yüzyıl sonrasında özellikle Konstantinopolis merkezli gelişen Monofizitizm ${ }^{29}$ ve Teopaşizm ${ }^{30}$ karşıtı Ortodoks Doktrini adına önemli bir argüman olma özelliği göstermiştir ${ }^{31}$. Sahnenin, en belirgin ikonografik elemanı, bir pagan dönemi figürü Hades'tir. $\operatorname{Hades}^{32}$, bu bağlamda dolaylı olarak kutsal metin bağ-

25 Leslie Brubaker, Vision and Meaning in Ninth-Century Byzantium. Images as Exegesis in the Homilies of Gregory of Naziansus (Cambridge: Cambridge University Press, 2008), 302.

26 Thomas'ın Şüphesi/Şüpheciliği-Mezar Başındaki Meryemler/Mür Taşıyan Kadınlar-Chairete en erken Diriliş siklusu içerisinde yer alan sahnelerdir. Geniş bilgi için bk. Konis, "From the Resurrection to the Ascension: Christ's Post-Resurrection Appearances in Byzantine Art (3rd - 12th c.)," 4-5.

27 Sahnenin, Mür Taşıyan Kadınlar/Myrophoroi olduğu görüşleri geniş için bk André Grabar, "La fresque des saintes femmes au tombeau à Doura," Cahiers Archéologiques 8 (1956); Konis, "From the Resurrection to the Ascension: Christ's Post-Resurrection Appearances in Byzantine Art (3rd - 12th c.)" 17 dipnotlar 4953; Carl H. Kraeling, The Excavations at Dura-Europos. Final Report VIII. Part II, The Christian Building (New York: J. Augustin Publisher, 1967), 80-90. Diğer taraftan Peppard çekimser kalan isimler arasında yer alır. Sahnenin, 10 Bakire Kız Benzetmesi de olabileceğini söyler. Geniş bilgi için bk. Micheal Peppard, "Illuminating the Dura-Europos Baptistery: Comparanda for the Female Figures," Journal of Early Christian Studies 20/4 (2012), 556-571.

28 Geniş bilgi için bk. Kartsonis, Anastasis, The Making of an Image, 143.

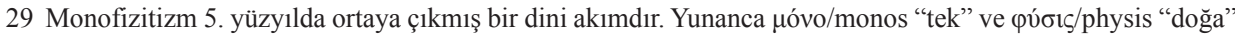
kelimelerinden türemiştir. Monofizit inanç Tanrı-İnsan tabiatlı İsa'nın varlı̆̆ına çözüm yolları bulmaya ça1şır. İnanca göre, İsa'nın enkarnasyonu öncesi Logos'un Tanrı tabiatı ayrıdır ve enkarnasyon ile birlikte insan tabiatı ile birleşmiştir. Alexander P. Kazhdan, "Monophysitism," The Oxford Dictionary of Byzantium 2 (New-York/Oxford: Oxford University Press, 1991), 1398-1399.

30 Tanrı'nın insan tabiatlı yanına vurgu yapması ve bu nedenle Tanrı'nın acı çekebileceği inancına verilen isimdir. Geniş bilgi için bk. https://www.encyclo.co.uk/meaning-of-Theopaschism.

31 Kartsonis, Anastasis, The Making of an Image, 227; Geniş bilgi için bk. Konis, "From the Resurrection to the Ascension: Christ's Post-Resurrection Appearances in Byzantine Art (3rd - 12th c.),"188-189.

32 Anastasis sahnesi ve Hades arasındaki ikonografik bağlantı geniş bilgi için bk., İlkgül Kaya Zenbilci, "Bizans Sanatında Alegorik Bir Figür: Hades," Trakya Üniversitesi Edebiyat Fakültesi Dergisi 11/21 (2021), 170-177. Anastasis sahnesinde, Hades figürünün teolojik kökenleri geniş bilgi için bk. Zeliha Şenel, "Bizans Sanatı'nda Anastasis Sahnesinin Teolojik Temelleri," Akademik Sosyal Araştırmalar Dergisi, 8/101 (2020), 301-309. 
lant111 Psalm/Mezmur 16:10'da ${ }^{33}$ geçen "לא־תעזב נפישי לשאול/Ruhumu Sheol'a terk et-

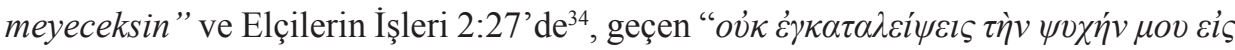

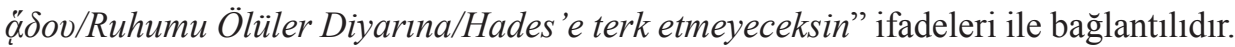

Giriş bölümünde de belirtildiği üzere, Hristiyan tasvir sanatında Diriliş Sonrası siklusu sahnelerinden; Balıkların Çoğaltılması, Emmaus Yolunda ve Emmaus'da Akşam Yemeği örnekleri nicel olarak azdır. İsa'nın enkarnasyonuna en önemli delillerden birisi olmasına rağmen, iki sahnenin özellikle Doğu/Bizans tasvir sanatında çok az yer alması bu bağlamda düşündürücüdür.

Dirilen İsa'nın, Emmaus Yolunda iki öğrencisine görünmesi, Kitab-1 Mukaddes’te dolaylı olarak anlatılan Teofani bağlantılı sahneler ile benzer detaylar içerir ${ }^{35}$. Özellikle Emmaus yolculuğu sonras1, Emmaus'da Akşam Yemeği sahnesi, İbrahim'in Konukseverliği/İbrahim ve Üç Melek sahnesi ile yakın ayrıntılar sergiler ${ }^{36}$. Bu detaylardan en önemlisi sofrada üç kişinin ve ekmeğin yer alması şeklindedir.

Ravenna San Vitale (6. yüzyıl) İbrahim'in Konukseverliği/İbrahim ve Üç Melek mozaik pano örneğinde, tıpkı Emmaus'da Akşam Yemeği sahnesinde olduğu gibi masa başında üç kişi ve ekmek detayları birbirleri ile benzerdir. San Vitale örneğinde, sahnenin devamında, İshak'ın Kurban Edilişi sahnesinin verilmesi, Emmaus Yolunda ve Emmaus'da Akşam Yemeği sahnelerinin Çarmıh olayı sonrası gerçekleşmesini hatırlatır. Bu bağlamda, kendini insanlık için adayan bir kurban figürü olarak İsa ${ }^{37}$, İshak'ın Kurban Edilişi sahnesindeki kurban figürü ile örtüşür ${ }^{38}$ (G. 16).

33 Geniş bilgi için bk. https://bible.oremus.org/?passage=Psalms\%2016:10\&version=nrsv.

34 Geniş bilgi için bk. https://bible.oremus.org/?passage=Acts\%202:27\&version=nrsv.

35 Yaratılış 18-19'da İbrahim ve eşi Sarah'ı ziyaret eden üç melek, Yaratılış 21:17-18'de İsmail ve Hacer'in uzaklaştırılması hikayesi anlatılırken, çöldeki çaresiz Hacer'e seslenen meleğin “Tanrı çocuğun sesini duydu" Yaratııı 28:16-17'de Yakup'un rüyasında "Rab burada ama ben farkına varamadım" ifadesi, Hakimler 6:11-12'deki Yoas'nn oğlu Gidyon'a görünen ve "Rab seninledir" diyen, Hakimler 13: 2-3'de Şimşon'un doğumu anlatılırken Dan oymağından Manoah'ın kısır karısına görünen ve ona Şimşon'un doğumunu vaat eden melekler imgelerinde hep bir Tanrı'nın görünümü/Teofani durumu söz konusudur.

36 İbrahim ve Sarah’1 ziyarete gelen melek görünümlü üç kişiden birisinin, aslında Rab olma ihtimali güçlüdür. Geniş bilgi için bk. Ann Sang-Keun, A Study of God's Encounter with Abraham in Genesis 18:1-15 Against the Background of the Abraham Narrative (Doktora tezi, Pretoria Üniversitesi, 2010), 19-22.

37 Çarmıhtaki İsa, İshak'ın Kurban Edilişi ve İbrahim 'in Konukseverliği/İbrahim ve Üç Melek gibi sahnelerin bemada yer alması, erken dönem kilise resim programında bir gelenektir. Adama ve adakta bulunma temas1nın bemada yer aldığı sahneler arasında, Roma San Vitale, Makedonya Ohrid Aya Sofya ve bazı Kapadokya kilise örnekleri vardır. Geniş bilgi için bk. Sirarpie Der Nersessian, "Program and Iconography of the Frescoes of the Parecclesion," The Kariye/Khora Djami V. 4 Studies in the Art of the Kariye/Khora Djami and Its Intellectual Background, ed. P. A. Underwood, (New Jersey: Princeton University Press, 1975), 31; Robin Cormack, "Visual Arts," The Cambridge Ancient History Vol. XIV Late Antiquity: Empire and Successors, A.D. 425-600 (s. 884-917), ed. A. Cameron, B. Ward-Perkins, M. Whitby, (Cambridge: Cambridge University Press, 2008), 891.

38 Çarmı sahnesi ve kurban ikonografisi konularında geniş bilgi için bk. Necla Kaplan, "Resimli Kutsal Kitap (Hristiyan) El Yazmalarındaki Kurban Sahnelerine Genel Bir Bakış," Kadim Akademi/Sosyal Bilimler Dergisi 1/1 (2017), 133-136, Feray Korucu Yağız, "Bizans Tasvir Sanatında Kurban Sahneleri” (Doktora tezi, Mimar Sinan Güzel Sanatlar Üniversitesi, 2019), 265-290; Kurban teması geniş bilgi için ayrıca bk. Feray Korucu Yağız, Bizans Sanatında Kurban Sahneleri (Ankara: Ürün Yayınları, 2020). 


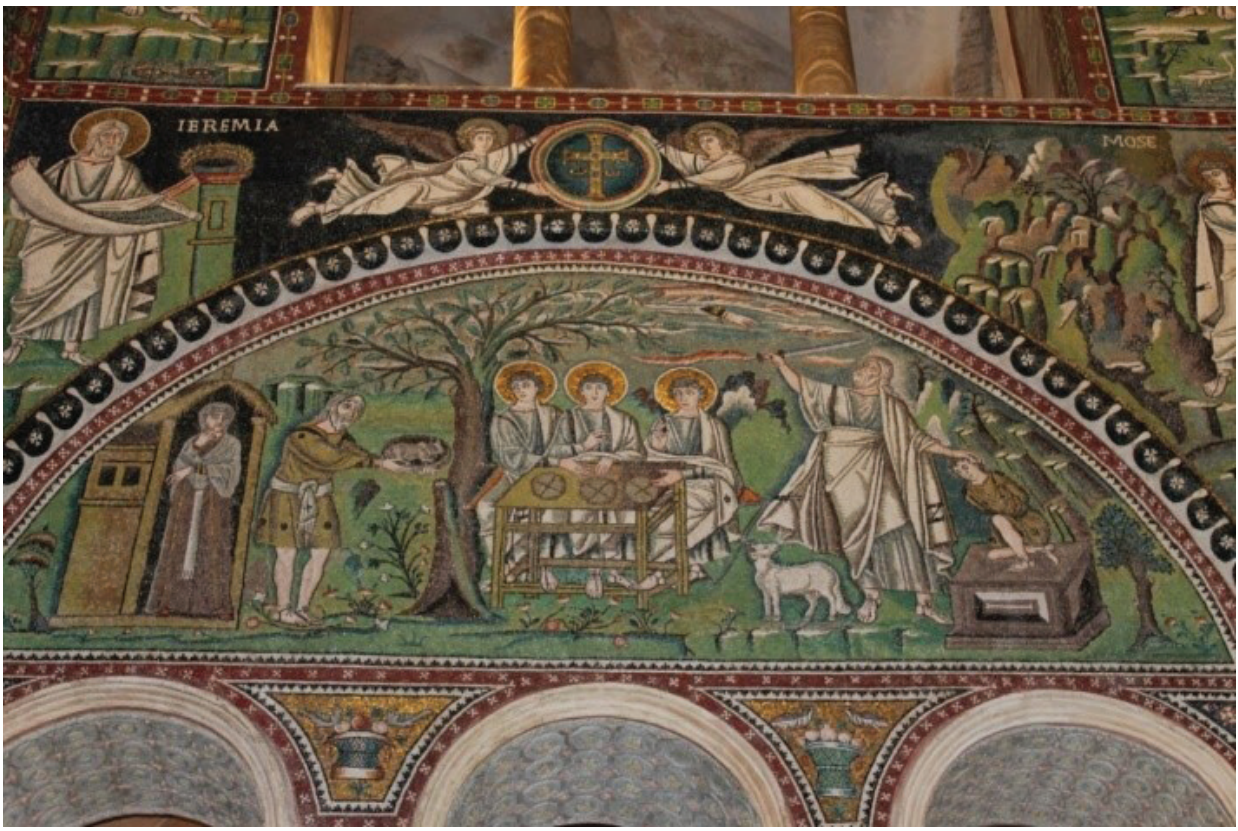

G. 16: İbrahim'in Konukseverliği/İbrahim ve Üç Melek ve İshak’ın Kurban Edilişi Sahneleri, Ravenna San Vitale Kilisesi, (Görsel Hatice Demir Arşivi, 2017)

İncelenen örnekler kapsamında, Emmaus Yolunda sahnesinin en erken tarihli Doğu

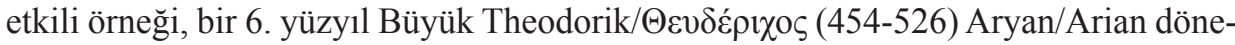
mi yapısı olan Sant' Apollinare Nuovo Bazilikası'nda görülür ${ }^{39}$. Bazilika mozaik pano programı kapsamında, Çarmıh ve bir Diriliş Sonrası sahnesi olan Emmaus Yolunda'yı da kapsayan siklus, erken dönem eğitici/açıklayıc1/öyküleyici etkili bir eğilim göste$\operatorname{rir}^{40}$. Günümüze gelebilen en erken tarihli örnek olan sahnenin, kilise resim programı içerisinde yer almasının nedenleri arasında, Ravenna kiliselerine özgü liturji vardır. Baumstark sahnenin, Ravenna kiliselerine ait Paskalya liturjisinde söylenen $\pi \varepsilon \rho \iota \kappa о \pi \eta ́ /$ pə'rıkəpi/perikopiler nedeniyle öyküleyici etkili olarak kilise resim programı içerisinde yer aldığına değinir ${ }^{41}$.

39 Ravenna'da yer alan Sant' Apollinare Nuovo Bazilikası, Theodorik’in saray şapeli olarak işlev görmüştür. Geniş bilgi için bk. Guglielmo De Angelis d'Ossat, "Spazialita e Simbolismo delle Basi-liche Ravennati," CorsiRav 17 (1970), 326; Mark J. Johnson, “Toward a History of Theoderic's Building Program,” Dumbarton Oaks Papers 42 (1988), 79; Cyrill Mango, Bizans Mimarisi, ed. Bülent İşler, (Ankara: Rekmay Ltd. Şti., 2006), 110.

40 Geç Antik ya da Erken Hristiyanlık döneminde, Judazim kökenli öykücü anlatım tekniği yeni doğmuş Hristiyan sanatı üzerinde etkili olmuştur. Ernst Kitzinger, Byzantine Art in the Making Main Lines of Stylistic Development in Mediterranean Art $3^{\text {rd }}-7^{\text {th }}$ Century (Cambridge-Massachusetts: Harvard University Press, 1995), 20; David Talbot Rice, Byzantine Art (Middlesex: Penguin Books, 1954), 126; Josef Strzygowski, “The Origin of Christian Art," The Burlington Magazine for Connoisseurs 20/5 (1911), 151.

41 Geniş bilgi için bk. Anton Baumstark, "I Mosaici di S. Apollinare Nuovo e L'antico Anno Liturgico Ravennate,” Rassegna Gregoriana IX (1910), 1-2. 
Çalışma kapsamında değerlendirilen Emmaus'da Akşam Yemeği sahnesi, Son Akşam Yemeği ya da Havarilerin Komünyonu sahneleri ile de benzer özellikler içermesi adına dikkate değerdir. Bu bağlamda sahne, İsa'nın Dirilişi sonrası gerçekleştiği için

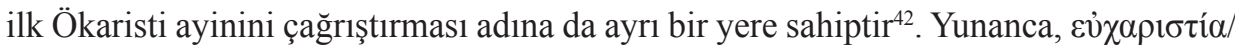
şükran ${ }^{43}$ olarak da tanımlanan Ökarastia'nın, liturjik bağlamda iki sunumu, Son Akşam Yemeği ${ }^{44}$ ve Liturjik Akşam Yemeği/Havarilerin Komünyonu ${ }^{45}$ Bizans tasvir sanatında farklı varyasyonları ile yerini alır. Özellikle çalışma kapsamında da değerlendirmeye alınan Sant' Apollinare Nuovo örneğindeki Son Akşam Yemeği, sahnenin kilise resim programı içerisindeki ilk örneklerinden birisi olması adına da önemlidir. Çalışma kapsamında değerlendirilen iki sahnenin (Emmaus Yolunda ve Emmaus'da Akşam Yemeği) genelde birlikte verildiği gözlemlenir. Sant' Apollinare Nuovo örneğinde Diriliş Sonrası siklusu sahnelerinden sadece Emmaus Yolunda sahnesinin yer almasının en büyük nedenlerinden birisinin yine Ravenna kiliselerine özgü Paskalya liturjisi dahilinde ele almak yerinde bir tespit olacaktır. Bu bağlamda Emmaus'da Akşam Yemeği sahnesinin, Sant' Apollinare Nuovo'da yer almamasının en önemli nedeni, Son Akşam Yemeği sahnesinin varlığı ile açıklanabilir. Böylece, Ökaristi bağlantılı bir sahnenin kilise resim programında ikinci bir kez tercih edilmeme olasılığ daha da güçlenir.

Bizans etkili diğer İtalya örnekleri arasında, 8. yüzyıla tarihlenen ve kısmen günümüze gelebilen Santa Maria Antiqua ${ }^{46}$ duvar resmi, 11. yüzyıla tarihlenen Güney İtalya üretimi kemik oyma tekniğinde levha ve 12. yüzyıla tarihlenen Monreale Katedrali ${ }^{47}$ mozaik pano yer alır.

42 Geniş bilgi için bk. Huffman "Emmaus Among the Resurrection Narratives," 220.

43 Geniş bilgi için bk. Eugene LaVerdiere, The Eucharist in the New Testament and the Early Church (Collegeville: Liturgical Press, 1996), 1-2.

44 Son Akşam Yemeği sahneleri özellikle Kapadokya kayaya oyma kilise duvar resmi örneklerinde 10.-13. yüzyıllar arasına tarihlenir. Geniş bilgi için bk. Zeynep Mercangöz, "Orta Çağ Hristiyanlık İnanışında Ökaristi ve Sanattaki Yansımaları: Bizans Sanatında Ökaristi Sembolleri," Sanat ve İnanç 2, (İstanbul: Mimar Sinan Güzel Sanatlar Üniversitesi, Türk Sanat Tarihi Uygulama ve Araştırma Merkezi, 2004), 43. Ayrıca bk. Merve Kalafat Yılmaz, "Kapadokya Bölgesi Bizans Dönemi Kiliselerinde Son Akşam Yemeği Konulu Duvar Resimleri” (Yüksek lisans tezi, İstanbul Üniversitesi, 2017). 4-184.

45 Liturjik Akşam Yemeği sahnelerini, Roma Kalliktus katakombu arkasoliumu, Demre Aziz Nikolaos Kilisesi prothesisi ve İstanbul Arkeoloji Müzesi gümüş stuma pateni örneklerinde görmek mümkündür. Geniş bilgi için bk. Mercangöz, "Orta Çağ Hristiyanlık İnanışında Ökaristi ve Sanattaki Yansımaları: Bizans Sanatında Ökaristi Sembolleri," 43-44.

46 Geniş bilgi için bk. Konis, "From the Resurrection to the Ascension: Christ's Post-Resurrection Appearances in Byzantine Art (3rd - 12th c.)," 75; Jones Nordhagen Per, Institutum Romanum Norvegiae. Acta ad Archaeologia et Artium Historiam Pertinentia, Volumen III: The Frescoes of John VII (A.D. 705-707) (Roma: "L’Erma" di Bretschneide, 1968.), 38; Jones Nordhagen, Per, "S. Maria Antiqua: The Frescoes of the Seventh Century," ActaAArtHist, VIII (1978), 89-142.

471182 yılına tarihlenen Monreale Katedrali mozaiklerinin yapımında Yunan kökenli sanatçıların çalıştığı düşünülmektedir. Bu bağlamda mozaik panolarda yer alan tasvirler Bizans üslubu göstermektedir. Geniş bilgi için bk. Charles Bayet, Byzantine Art (New-York: Parkstone International Press, 2009), 148. Özellikle kilisenin üst düzey alanındaki mozaik pano tasvirlerindeki öykücü etkili sahne dizilişleri ve sahnelerdeki olayları pekiştiren kitabeler, Bizans tasvir geleneği gösterir. Geniş bilgi için bk. Otto Demus, Byzantine Mosaic Decoration. Aspects of Monumental Art in Byzantium (Boston: Boston \& Art Shop, 1964), 31, 66. 
Doğu/Bizans etkili örnekler kapsamında sahnelerin, el yazmalarında neredeyse hiç tercih edilmediği gözlemlenir. Bu bağlamda sadece 11. ve 14. yüzy1llara tarihlenen üç el yazması kitap resmi örneğinde sahnenin yer aldığı gözlemlenir.

Doğu/Bizans etkisi altındaki en geç tarihli örnek, 14. yüzyıla tarihlenen Sırbistan Graçanitsa/Gračanica Manastırına aittir. Duvar resmi, Bizans Paleologos Rönesans'1 etkisi gösterir ${ }^{48}$. Bu bağlamda, çalışma kapsamında Doğu/Bizans etkili örneklerin, İtalya-Sırbistan gibi Batı ile etkileşimin yoğun olduğu topraklarda görülmesi, Anadolu-Suriye-Ermenistan gibi doğu topraklarında tercih edilmemiş olması da ayrıca bir sorunsal teşkil etmektedir.

Çalışma kapsamında değerlendirmeye alınan Batı/Latin kökenli örneklerin nicel olarak çokluğu dikkat çeker. Sahne, tasvir sanatının hemen hemen her alanında (duvar resmi, kitap resmi, küçük el sanatları örnekleri) yer alır. Sahnenin Batı kökenli en erken tarihli örneklerinden birisi, 9. yüzyıla tarihlenen Karolenj dönemi bir fildişi levhadır. Levha, Emmaus Yolunda ve Emmaus'da Akşam Yemeği sahnelerinin birlikte verildiği bir örnek olması adına da önemlidir. Latin kitap resmi örneklerinde, Bizans'ın aksine ikonografik detaylarda bir birliktelik olmadığı gözlemlenir. Diğer taraftan örneklerin 15. yüzyıl ile sınırlandırıldığı çalışmada, Duccio di Buoninsegna'nın 14. yüzyıl başına tarihlenen Siena Katedrali için yapmış olduğu ahşap üzerine tempera tekniğindeki ${ }^{49}$ altar parçası örneği, teknik ve ikonografik detaylarda Bizans etkisi gösterir ${ }^{50}$.

Sahnenin, Batı örneklerinde nicel olarak çokluk göstermesi konusunda farklı görüşler vardır. Bu görüşlerden, Konis'in savladığı Batılı hacıların Kutsal Topraklara yapmış olduğu kutsal yolculuk sirkülasyonu bağlantısı en akla yatkın olanıdır ${ }^{51}$. Hac olayının başı başına "yol" metaforu ile ilintili olması nedeniyle, geç dönem Latin

48 Geniş bilgi için bk. The Predicament of Serbian Orthodox Holy Places in Kosovo and Metohia Elements for a Historical, Legal and Conservational Understanding, ed. Dragan M. Mitrović, (Belgrade: University of Belgrade Publication, 2010), 81.

49 Siena Okulu'nun en önemli özelliklerinden birisi, ahşap üzerine tempera tekniğinde taşınabilir panolar üretimidir. Geniş bilgi için bk. Semra Germaner, "Siena Okulu," Eczacıbaşı Sanat Ansiklopedisi c. III (İstanbul: YEM/Yapı Endüstri Merkezi Yayınları, 1997), 1663. Çalışma kapsamında ele alına örnek bu bağlamda hem Bizans hem de Siena Okulu özellikleri gösterir.

50 Duccio ve Siena Okulu'nun eserlerinde Bizans geleneğini ikonografik ve teknik olarak devam etmiştir. Hills, bu geleneğin teknik olarak altın yaldız ve parlak renkler kullanımı ile devam ettiğine değinir. Geniş bilgi için bk. Paul Hills, "Pattern, Plain and Splendour of Gold in Sienese Painting: Duccio, Simone Martini and Pietro Lorenzetti," The Light of Early Italian Painting (New Haven: Yale University Press, 1987), 97-98; ayrıca bk. Evren Kavuncu, "Seçkiler Üzerinden 13. yy'dan 18.yy'a "Son Akşam Yemeği” İncelenmesi," Sanat Dergisi 25 (2014), 69; Stubblebine, Duccio'nun Bizans el yazmaları resimlerinden etkilendiğini ve modelleme yaparak üretimde bulunduğunu savlar. Bu bağlamda Duccio’nun çalışmalarında, ikonografik olarak kısmen de olsa Otto döneminden etkilenme gözlemlenirken, eserlerinin birçoğunda ikonografik ve figürlerin kompozisyona yerleştirilmesi noktasında, Bizans etkisi hissedilir. Geniş bilgi için bk. James H. Stubblebine, "Byzantine Sources for the Iconography of Duccio's Maestà," The Art Bulletin 57/2 (1975): 176-185.

51 Geniş bilgi için bk. Konis, "From the Resurrection to the Ascension: Christ's Post-Resurrection Appearances in Byzantine Art (3rd - 12th c.)," 16, 27, 38, 79. 
örneklerinde Emmaus Yolunda sahnesi bu bağlamda Kutsal Yolculuk ile örtüşür. Batılı hacıların yolculuk metaforu ile başlattığı bu ikonografinin kökeni, Yunan felsefesi kaynaklı "yol" metaforu ile de benzerlik gösterir. Bu bağlamda, Emmaus Yolunda için kullanılan "yol", Antik Yunan felsefesine dayanan bir metafor olması adına da önemlidir. Platon’nun Symposium/Şölen kitabında, yol: ódó s olarak geçer. Bu özelliği ile yol, hakikat ve bilgi sahibi olma ile ilintilidir ${ }^{52}$ ve bu yönüyle mecazi bir anlam ile yüklüdür. Symposium/Şölen kitabının giriş bölümünde, aşkı arayan iki öğrencinin uzun zamandır görmedikleri öğretmenlerinin yolculukları esnasında yanında belirmesi ve yolculuğun akabinde ritüel dahilinde gerçekleşen symposium/şölen sonrası gözden kaybolması, Kitab-1 Mukaddes Emmaus Yolunda ve Emmaus'da Akşam Yemeği olayı ile benzer ayrıntılar içerir ${ }^{53}$. Bu bağlamda, burada bahsi geçen metaforik "yol" benzetmesinin kökenini Antik dönem Yunan felsefesinde arayan görüşler mevcuttur. Bu görüşlerden Havari Luka'nın, Yunan felsefesi kaynaklı bu temayı, yaşadığı GrekoRoman toplumunda Yahudi ve Centiller arasında da kabul edilmesini kolaylaştırma amaçlı olarak bir edebî argüman niteliğinde kullandığını savunan görüş, en güçlü olanidir ${ }^{54}$.

Özellikle Haçlı seferleri ile birlikte Kutsal Topraklara başlayan Hac yolculuğunun etkilerini, sahnenin tasvirinde de görmek mümkündür. Emmaus Yolunda sahnesinin tasvirlerinde dikkat çeken en önemli detaylardan birisi, kendi içerisinde bir birliktelik göstermeyen Emmaus köyünün tasvirinde gözlemlenir. Çalışma kapsamında Doğu örneklerinde sadece Graçanitsa Kilisesi duvar resminde Bizans'a özgü bir mimari üslup gözlemlenirken, diğer örneklerdeki mimari üslupta farklı yorumlar ile karşılaş1lır. Sahnenin mimari tasvirinde gözlemlenen farklılık nedenleri arasında, Emmaus'un yerinin tespit edilememesi ve Emmaus için önerilen dört yerden üçü ile bilgilerin çoğunun farklı cemaatlere ait Latin Hacı kayıtlarında yer alması vardır.

$\mathrm{Bu}$ tarihi hacı kayıtlarından en önemlisi, Itinerarium Burdigalense/Bordo Seyahatnamesi'dir. Itinerarium Burdigalense'da Emmaus, Nikopolis olarak geçer ${ }^{55}$. McRay, Nikopolis'te 1875-1930 tarihleri arasında yapılan kazılar sonucunda; bir Roma Evi, bir vaftizhane, biri büyük olmak üzere 3.- 6. yüzy1llar arasına tarihlenen iki bazilika ve 12. yüzyıla tarihlenen bir Latin Haçlı Kilisesi'nin varlığına değinir. Diğer taraftan bir Dominikan tarikatı papazı Louis-Hugues Vincent'1n 1924-1930 tarihleri arasında yapmış olduğu kazılarda ortaya çıkardığı Roma evinin, Klopas'ın Evi olma ihtimali üzerinde de durur ${ }^{56}$. Emmaus için önerilen diğer bir yerleşim yeri günümüz-

52 Geniş bilgi için bk. "The Greek Road to Emmaus," 78-82.

53 Geniş bilgi için bk. Plato, Symposium, çev. Walter, Hamilton, (London: The Penguin Books), 1956,76-85.

54 Geniş bilgi için bk. "The Greek Road to Emmaus," 78-80.

55 Routley, "Finding Emmaus: The Problem of the Geographical Location of the Biblical Site," 6; Hershel

Shanks, "Emmaus: "Where Christ Appeared," Biblical Archaeology Review 34/2 (2008), 44; John McRay,

Archaeology and the New Testament (Grand Rapids/Michigan: Baker Academic, 2008), 221.

56 McRay, Archaeology and the New Testament, 51, 221. 
deki Filistin-Batı Şeria yakınlarında yer alan Al-Qubeiba'dır. Bu bölge, Fransisken Tarikatı himayesinde yer alan Custodia Terrce Sanctce olarak da bilinir. Yerleşim yeri, Haçlılar zamanında Franklar tarafından kurulan ve Parva Mahomeria isminde bir köy olarak da anılır ${ }^{57}$. Al-Qubeiba'da, Fransisken rahip Bellarmino Bagatti'nin 1940'larda yapmış olduğu kazılarda, erken döneme tarihlenen bir Bizans Kilisesi üzerine inşa edilen bir Haçlı Bazilikası, bir erken dönem Roma Evi ve Helenistik döneme kadar uzanan bir yerleşim yeri ortaya çıkarılmıştır ${ }^{58}$. Kudüs'e $10 \mathrm{~km}$. uzaklıkta olan Abu Ghosh yerleşim bölgesi Emmaus için önerilen bir diğer yerdir. Özellikle Haçlılar zamanında burada bir pınar olması nedeniyle Emmaus olarak da anılmıştır. Haçlılar bölgede, Fontenoide Kalesini ve 1141 tarihinde bir kilise inşa etmişlerdir. Günümüze gelebilen Haçlı ve Diriliş Kiliseleri tarih boyunca hep Benediktin Manastırı kontrolü altında kalmıştır ${ }^{59}$. Emmaus olabileceği iddia edilen son yerleşim yeri, Qaloniyeh/ Colonia/Motza'dır. Burada yapılan kazılar sonucunda Herod zamanına tarihlenen sur kalıntılarına rastlanmıştır ${ }^{60}$. Bu bağlamda özellikle Abu Ghosh ve Qaloniyeh/Colonia, Motza'da sur kalıntıları ve kale yapılarının varlığı, çalışma kapsamında incelenen örneklerde de gözlemlenir. Sant' Apollinare Nuovo, Monreale, Cod. gr. 74 fol. 162v, Maestà ve W. 174/Eberhand von Greiffenklau Dua Kitabı, fol. 99v. örneklerinde farklı mimari üsluplarda kale-sur-sur kapıs1-kilise gibi mimari yapılar ve mimari elemanlar ile karşılaşılır. Buradan şöyle bir sonuç çıkarmak mümkün olabilir: Emmaus'un yerinin bilinmezliği, yeri için önerilen yerlerin farklılığı, bu yerlerin farklı Latin/ Haçlı kökenli dini yapılanmanın kontrolü altında oluşu ve hemen hemen hepsinin Hac bölgesi olarak kabul edilmesi sahnenin Batı örneklerinde hem nicelik olarak çok oluşuna hem de Emmaus'un tasvirindeki mimari üslup farklılığına açıklama getirir.

Diğer taraftan Emmaus, Doğu örneklerinin çoğunda düz bir ova şeklinde tasvir

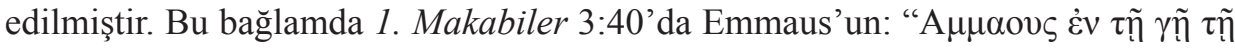
$\pi \varepsilon \delta$ เท̣̃/Ovada düz bir arazi” olarak geçmesi, en önemli tasvir kaynağı olma ihtimalini güçlendiririr ${ }^{61}$.

Çalışma kapsamında incelenen Doğu ile Batı örnekleri arasındaki ikonografik farkl11ıklar, Emmaus'da Akşam Yemeği sahnesinde de gözlemlenir. Batı örneklerinde, kısmen ikonografinin dışına çıkılmıştır. Luka 24:30'da "Onlarla sofrada otururken

57 Denys Pringle, The Churches of the Crusaders Kingdom of Jerusalem (Cambridge: Cambridge University Press, 1998), 167; Reinhold Röhricht, Regesta Regni Hierosolymitani (Mxcvii-Mccxci) (Oeniponti: Libraria Academia Wagneriana, 1893), 88.

58 Geniş bilgi için bk. Bellarmino Bagatti, Emmaus-Qubeibeh: The Results of Excavations at Emmaus-Qubeibeh and Nearby Sites (1873, 1887-1890, 1900-1902, 1940-1944), çev. Raphael Bonanno, (Jerusalem: Franciscan Printing Press, 1993), 78-82, 174-175.

59 Shanks, "Emmaus, Where Christ Appeared," 42; Routley, "Finding Emmaus: The Problem of the Geographical Location of the Biblical Site," 9.

60 Egon H. E. Lass, "Is Motza Biblical Emmaus?," Biblical Archaeology Review 34/6 (2008), 16; Shanks, "Emmaus, Where Christ Appeared," 42; Routley, "Finding Emmaus: The Problem of the Geographical Location of the Biblical Site," 9-10.

61 Routley, "Finding Emmaus: The Problem of the Geographical Location of the Biblical Site," 5. 
Is a ekmek aldl, şükretti ve ekmeği bölüp onlara verdi." ifadesinin dışında ikonografik bir detay olarak Royal MS 1 D ve MS M 643 örneklerinde bıçak gözlemlenir. Doğu örneklerinde, sofrada ya da İsa'nın elinde sadece ekmek varken, Batı örneklerinde sofrada balık (Royal MS 1 D, MS M 643, MS St. Godehard) ve içecek de vardır. Palermo/Monreale Katedrali örneğindeki sahneler bu bağlamda bir geçiş niteliği taşır.

Doğu/Bizans ve Batı/Latin örnekleri arasındaki en önemli ikonografik farklılıklardan bir diğeri, İsa'nın tasvirindeki detaylarda görülür. Doğu/Bizans örneklerinde İsa'nın üzerinde genelde himation ve khiton varken Batı/Latin örneklerinde İsa'nın üzerinde posttan bir pelerin, omuz çantası, kasket ya da hasır şapka ve elinde bir asa olduğu gözlemlenir. Bu bağlamda İsa bir hacıyı andırmaktadır ${ }^{62}$.

İncelenen Doğu ve Batı örneklerinin çoğunda, İsa'nın yanındaki iki figür, halesiz tasvir edilmiştir. Bu bağlamda, çalışma konusunu da oluşturan Kitab-1 Mukaddes Luka 24:13-35 Emmaus Yolunda İki Öğrenci babında da olduğu gibi, bu iki kişinin statüleri “öğrenci” olarak verilmiştir. Öğrencilerden sadece Klopas'ın ismi verilirken diğerinin adı belli değildir. Bu bağlamda Klopas ve diğer öğrencinin kim oldukları konusu da tartışmalıdır. İsa'nın Emmaus'da Akşam Yemeği sonrası bu iki öğrencinin gözlerinin önünden kaybolması sonrası, Luka 24: 33'de belirtildiği üzere, "Kalkıp hemen Yeruşalim'e döndüler. Onbirler'e ve onlarla birlikte olanları toplanmış buldular..." ifadesinde de geçtiği üzere iki öğrenci, olanları Onbirler'e ve diğerlerine anlatmışlardır. Bu bağlamda, kutsal metinde Onbirler ifadesinin geçmesi, bu iki kişinin havari olamayacağına bir delil niteliğindedir. Diğer taraftan İsa'nın takipçileri/öğrencilerinin sayıları da Kitab-1 Mukaddes'te farklılık gösterir. Örneğin, Elçilerin İşleri 1:15-16'da yüz yirmi, Luka 10:1'de Yetmişler şeklindedir. Bu nedenle, Klopas'in kimliğinin de tartışmalı olduğu göz önünde bulundurulursa bu iki kişinin havari olmaması nedeniyle örneklerin çoğunda halesiz tasvir edilmiş olma ihtimali de böylece güçlenmiş olur.

\section{Sonuç}

İsa'nın Diriliş anı ve sonrası ile ilgili olan sahneler, Onun hem insani hem de tanrısal yanına göndermede bulunarak enkarnasyonuna bir delil teşkil etmektedir. $\mathrm{Bu}$ bağlamda, Hristiyan inancı kapsamında erken dönemlerden başlayarak gerek kilise içerisindeki liturjide ve gerekse liturjiyi destekleyen Hristiyan tasvir sanatında Diriliş sonrası sahneleri ${ }^{63}$ önemli bir yere sahip olmuştur.

62 Emmaus Yolunda sahnesi batı örneklerinde İsa'nın bir hacı kıyafetleri içerisinde tasvir edilmesi ile ilgili geniş bilgi için bk. Leslie Ross, "Road to Emmaus," Medieval Art: A Topical Dictionary (Westport-ConnecticutLondon: Greenwood Press, 1996), 217.

63 Mezar Başında Meryemler/Myrophoroi/Mür Taşıyan Kadınlar, Chairete, Noli me Tangere, Petrus ve Yuhanna Mezar Başında, Thomas'ın Şüphesi/Şüpheciliğii, Balıkların Çoğalışı, Emmaus Yolunda-Emmaus'da Akşam Yemeği, İsa, Onbirler’e Görünüyor ve Anastasis. 
Sahnelerden, Mür Taşıyan Kadınlar ve Anastasis, tüm Hristiyan coğrafyası içerisinde en yaygın Diriliş Sonrası sahneleri olarak yerini korumuştur. Çalışmanın konusunu oluşturan iki sahnenin (Emmaus Yolunda ve Emmaus'da Akşam Yemeği) literatür ve liturjideki yerinin yaygın olmasının aksine, özellikle Bizans coğrafyasını kapsayan tasvir sanatında yerinin az olmasına karşı, Batı örneklerinde sıklıkla tercih edilmiş olma sorunsalı bu makalenin ana hatlarını oluşturmuştur. Bu bağlamda; sahnelerin Latin örneklerinde nicel olarak çok olması nedeninin kökeninde, Antik dönem Yunan felsefesinde yer alan hac bağlantılı yol metaforunun etkili olma ihtimali üzerinde durulmuştur. Özellikle Batı kökenli sahnelerde 11. yüzyıl sonrasında nicel olarak bir artış gözlemlenir. Bu bağlamda, Antik dönem hac/yol kavramı, Latin Haçlı seferleri ile pekişmiş ve özellikle Emmaus Yolunda sahnesi metaforik bir ruhani yolculuğu temsil etmiştir. Özellikle Batı/Latin örneklerinde, hac ve yolculuk kavramları ile bağlantılı olarak arka planda tasvir edilen Emmaus'un bir hac ziyaret bölgesi olması nedeniyle özellikle vurgulandığı gözlemlenir. Aynı vurgulu tasviri bir hacı kıyafeti içerisinde tasvir edilen İsa' da da görmek mümkündür.

Sonuç olarak, Emmaus Yolunda ve Emmaus'da Akşam Yemeği sahneleri, Doğu ve Batı örnekleri kapsamında farklı ikonografik detaylar ile Hristiyan tasvir sanatında önemli bir yere sahip olmuştur.

\footnotetext{
Hakem Değerlendirmesi: Diş bağımsız.

Çıkar Çatışması: Yazar çıkar çatışması bildirmemiştir.

Finansal Destek: Yazar bu çalışma için finansal destek almadığını beyan etmiştir.

Peer-review: Externally peer-reviewed.

Conflict of Interest: The author has no conflict of interest to declare.

Grant Support: The author declared that this study has received no financial support.
}

\section{Kaynakça/References}

Bagatti, Bellarmino. Emmaus-Qubeibeh: The Results of Excavations at Emmaus-Qubeibeh and Nearby Sites (1873, 1887-1890, 1900-1902, 1940-1944). Çev. Raphael Bonanno. Jerusalem: Franciscan Printing Press, 1993.

Baumstark, Anton. "I Mosaici di S. Apollinare Nuovo e L'antico Anno Liturgico Ravennate." Rassegna Gregoriana IX (1910): 1-2.

Bayet, Charles. Byzantine Art. New-York: Parkstone International Press, 2009.

Blacketer, Raymond A. "Word and Sacrament on the Road to Emmaus: Homiletical Reflections on Luke 24:13-35." CTJ 38 (2003): 321-329.

Bowen, Clayton Raymond. "The Emmaus Disciples and the Purposes of Luke." The Biblical World 35/4 (1910): 234-245.

Brubaker, Leslie. Vision and Meaning in Ninth-Century Byzantium. Images as Exegesis in the Homilies of Gregory of Naziansus. Cambridge: Cambridge University Press, 2008.

Brubaker, Leslie. Inventing Byzantine Iconoclasm. Bristol: Bristol Classical Press, 2012. 
Bucur, Bogdan. "Blinded by Invisible Light Revisiting the Emmaus Story (Luke 24,13-35)." Ephemerides Theologicae Lovanienses 90/4 (2014): 685-707.

Cormack, Robin. "Visual Arts." The Cambridge Ancient History Vol. XIV Late Antiquity: Empire and Successors, A.D. 425-600 (s. 884-917). Ed. A. Cameron, B. Ward-Perkins, M. Whitby. Cambridge: Cambridge University Press, 2008, 884-917.

Corrigan, Kathleen. Visual Polemics in the Ninth-Century Byzantine Psalters. Cambridge-NewYork: Cambridge University Press, 1992.

De Angelis d'Ossat, Guglielmo. "Spazialita e Simbolismo delle Basi-liche Ravennati." CorsiRav 17 (1970): 313-333.

Der Nersessian, Sirarpie. "Program and Iconography of the Frescoes of the Parecclesion." The Kariye/Khora Djami V. 4 Studies in the Art of the Kariye/Khora Djami and Its Intellectual Background. Ed. P. A. Underwood. New Jersey: Princeton University Press, 1975, 303-350.

Demus, Otto. Byzantine Mosaic Decoration. Aspects of Monumental Art in Byzantium. Boston: Boston \& Art Shop, 1964.

Delvoye, Charles. "Bizans Resim Sanatının Ana Temayülleri.” Ankara Üniversitesi Dil ve Tarih Coğrafya Fakültesi Dergisi 22/3-4 (1964): 303-318.

Dinkler, Michal Beth. "Building Character on the Road to Emmaus: Lukan Characterization in Contemporary Literary Perspective." Journal of Biblical Literature 136/3 (2017): 687-706.

Evseeva, Liliya M. "Liturgical Drama as a Source of the Monreale Mosaics." Series Byzantina 8 (2010): 67-84.

Johnson, Mark J. “Toward a History of Theoderic's Building Program.” Dumbarton Oaks Papers 42 (1988): 73-96.

Germaner, Semra. "Siena Okulu.” Eczacıbaşı Sanat Ansiklopedisi. III. İstanbul: YEM/Yapı Endüstri Merkezi Yayınları, 1997, 1663.

Grabar, André. "La Fresque des Saintes Femmes au Tombeau à Doura." Cahiers Archéologiques 8 (1956): 9-26.

Grabar, André. "Sur Plusieurs Images Insolites du Christ Dans le Psautier Chloudov." $\triangle X A E, I V / 10$ (1980-81): 11-16.

Grabar, André. L'Iconoclasme Byzantine, Le Dossier Archéologique. Paris: College de France, 1984.

Hills, Paul. "Pattern, Plain and Splendour of Gold in Sienese Painting: Duccio, Simone Martini and Pietro Lorenzetti." The Light of Early Italian Painting. New Haven: Yale University Press, 1987, 95-157.

Huffman, Norman. "Emmaus Among the Resurrection Narratives." Journal of Biblical Literature 64/2 (1945): 205- 226.

Kalafat Yılmaz, Merve. "Kapadokya Bölgesi Bizans Dönemi Kiliselerinde Son Akşam Yemeği Konulu Duvar Resimleri.” Yüksek Lisans tezi, İstanbul Üniversitesi, 2017.

Kaplan, Necla. "Resimli Kutsal Kitap (Hristiyan) El Yazmalarındaki Kurban Sahnelerine Genel Bir Bakış.” Kadim Akademi Sosyal Bilimler Dergisi/1 (2017): 125-137.

Kartsonis, Anna. Anastasis, The Making of an Image. Princeton: Princeton University Press, 1986.

Kavuncu, Evren. “Seçkiler Üzerinden 13.yy’dan 18.yy’a “Son Akşam Yemeği” İncelenmesi." Sanat Dergisi 25 (2014): 67-79.

Kazhdan, Alexander P. "Incarnation." The Oxford Dictionary of Byzantium. 2. New-York/Oxford: Oxford University Press, 1991, 990-991. 
Kazhdan, Alexander P. (1991). "Monophysitism." The Oxford Dictionary of Byzantium. 2. NewYork/Oxford: Oxford University Press, 1991, 1398-1399.

Kidd, Peter. "Contents and Codicology." Dombibliothek Hildesheim The Albani Psalter. Simbach am Inn: Verlag Müller \& Schindler, 2008, 41-144.

Kitzinger, Ernst. Byzantine Art in the Making Main Lines of Stylistic Development in Mediterranean Art $3^{\text {rd }}-7^{\text {th }}$ Century. Cambridge-Massachusetts: Harvard University Press, 1995.

Kraeling, H. Carl. The Excavations at Dura-Europos. Final Report VIII. Part II, The Christian Building. New York: J. Augustin Publisher, 1967.

Konis, Polyvios. "From the Resurrection to the Ascension: Christ's Post-Resurrection Appearances in Byzantine Art (3rd - 12th c.).” Doktora tezi, Birmingham Üniversitesi, 2008.

Lass, Egon H.E. “Is Motza Biblical Emmaus?.” Biblical Archaeology Review 34/6 (2008), 16.

LaVerdiere, Eugene. The Eucharist in the New Testament and the Early Church. Collegeville: Liturgical Press, 1996.

Mango, Cyrill. Bizans Mimarisi. Ed. Bülent İşler. Ankara: Rekmay Ltd. Şti., 2006.

McRay, John. Archaeology and the New Testament. Grand Rapids/Michigan: Baker Academic, 2008.

Meek, Russell L. "With Christ on the Road to Emmaus." The Journal for Baptist Theology and Ministry 14/1 (2017): 3-12.

Mercangöz, Zeynep. “Orta Çağ Hristiyanlık İnanışında Ökaristi ve Sanattaki Yansımaları: Bizans Sanatında Ökaristi Sembolleri.” Sanat ve Inanç 2. İstanbul: Mimar Sinan Güzel Sanatlar Üniversitesi, Türk Sanat Tarihi Uygulama ve Araştırma Merkezi, 2004, 43-52.

Morris, Derek. "The Emmaus Road-Part 1-2-3, The Testimony of Cleopas", Erişim 21 Haziran 2021. https://rilogyscriptureresources.com/wp-content/uploads/2013/04/Emmaus-Road.pdf

Nordhagen Per, Jones. Institutum Romanum Norvegiae. Acta ad Archaeologia et Artium Historiam Pertinentia, Volumen III: The Frescoes of John VII (A.D. 705-707), Roma: L'Erma” di Bretschneide, 1968.

Nordhagen, Per, Jones. "S. Maria Antiqua: The Frescoes of the Seventh Century." ActaAArtHist VIII (1978):89-142.

Omont, Henri. Evangiles avec Peintures Byzantine du XIe siecle. Tome II, Reproduction des 361 miniatures du Manuscrit Grec 74 de la Bibliothèque Nationale, Paris : Berthaud frères, 1908.

Peppard, Michael. "Illuminating the Dura-Europos Baptistery: Comparanda for the Female Figures." Journal of Early Christian Studies 20/4 (2012): 543-574.

Plato, "Symposium", Walter, Hamilton (çev.). London: The Penguin Books, 1956.

Pringle, Denys. The Churches of the Crusaders Kingdom of Jerusalem. Cambridge: Cambridge University Press, 1998.

Rice, David, Talbot. Byzantine Art. Middlesex: Penguin Books, 1954.

Ross, Leslie. "Road to Emmaus." Medieval Art: A Topical Dictionary. Westport-ConnecticutLondon: Greenwood Press, 1996, 217.

Routley Jonathan. "Finding Emmaus: The Problem of the Geographical Location of the Biblical Site” Erişim 22.01.2021

https://www.academia.edu/37192570/Finding_Emmaus_The_Problem_of_the_Geographical_ Location_of_the_Biblical_Site

Röhricht, Reinhold. Regesta Regni Hierosolymitani (Mxcvii-Mccxci),Oeniponti: Libraria Academia Wagneriana, 1893. 
Sang-Keun, Ann. A Study of God's Encounter with Abraham in Genesis 18:1-15 Against the Background of the Abraham Narrative. Doktora tezi, University of Pretoria, 2010.

Shanks, Hershel. "Emmaus: Where Christ Appeared." Biblical Archaeology Review 34/2 (2008): 40-51.

Stubblebine, James H. "Byzantine Sources for the Iconography of Duccio's Maestà." The Art Bulletin, 57/2 (1975): 176-185.

Strzygowski, Josef. (1911). "The Origin of Christian Art." The Burlington Magazine for Connoisseurs, 20/05 (1911): 146-153.

The Predicament of Serbian Orthodox Holy Places in Kosovo and Metohia Elements for a Historical, Legal and Conservational Understanding. Ed. Dragan M. Mitrović. Belgrade: University of Belgrade Publication, 2010.

The 'Painter's Manual' of Dionysius of Fourna an English Translation with Commentary, of cod. gr. 708 in the Saltykov-Shchedrin State Public Library, Leningrad. Çev. Paul Hetherington. London: The Sagittarius Press, 1974.

Şenel, Zeliha. "Bizans Sanatı'nda Anastasis Sahnesinin Teolojik Temelleri.” Akademik Sosyal Araştırmalar Dergisi 8/101 (2020): 296-311.

Velmans, Tania. Le Tétraévangile de la Laurentienne : Florence, Laur.VI 23, Paris : Bibliothèque des Cahiers Archéologiques/6, 1971.

Zenbilci Kaya, İlkgül. "Bizans Sanatında Alegorik Bir Figür: Hades.” Trakya Üniversitesi Edebiyat Fakültesi Dergisi 11/21 (2021): 153-189.

Yağız Korucu, Feray. "Bizans Tasvir Sanatında Kurban Sahneleri.” Doktora tezi, Mimar Sinan Güzel Sanatlar Üniversitesi, 2019.

Yağız Korucu, Feray. Bizans Sanatında Kurban Sahneleri. Ankara: Ürün Yayınları, 2020.

https://thedigitalwalters.org/Data/WaltersManuscripts/html/W174/ Erişim 20 Kasım 2020.

https:/www.wga.hu/cgi-bin/search.cgi?author=\&time=any\&school=any\&form=any\&type=any \& title $=$ emmaus $+\&$ comment $=\&$ location $=\&$ from $=20 \& \max =20 \&$ format $=5$ Erişim 20 Ocak 2021.

https://www.metmuseum.org/art/collection/search/471970 Erişim 20 Ocak 2021.

http://www.travelingintuscany.com/art/duccio/maestabackpanels.htm Erişim 22 Ocak 2021.

https://bible.oremus.org/?passage=Psalms\%2016:10\&version=nrsv Erişim 18 Aralık 2020.

https://bible.oremus.org/?passage=Acts\%202:27\&version=nrsv Erişim18 Aralık 2020.

https://www.themorgan.org/manuscript/141641 Erişim 1 Ocak 2021.

https://www.dombibliothek-hildesheim.de/en/st-albans-psalter Erişim 14 Aralık 2020.

"The Greek Road to Emmaus." https://www.apsu.edu/philomathes/RossPhilomathes2020Online. pdf Erişim 12 Ocak 2021.

https://www.encyclo.co.uk/meaning-of-Theopaschism Erişim 30 Nisan 2021. 
